\title{
Trace gas composition in the Asian summer monsoon anticyclone: a case study based on aircraft observations and model simulations
}

\author{
Klaus-D. Gottschaldt ${ }^{1}$, Hans Schlager ${ }^{1}$, Robert Baumann ${ }^{1}$, Heiko Bozem ${ }^{2}$, Veronika Eyring ${ }^{1}$, Peter Hoor ${ }^{2}$, \\ Patrick Jöckel $^{1}$, Tina Jurkat ${ }^{1}$, Christiane Voigt ${ }^{1,2}$, Andreas Zahn ${ }^{3}$, and Helmut Ziereis ${ }^{1}$ \\ ${ }^{1}$ Deutsches Zentrum für Luft- und Raumfahrt (DLR), Institut für Physik der Atmosphäre, Oberpfaffenhofen, Germany \\ ${ }^{2}$ Johannes Gutenberg-Universität, Institut für Physik der Atmosphäre, Mainz, Germany \\ ${ }^{3}$ Karlsruher Institut für Technologie (KIT), Institut für Meteorologie und Klimaforschung, Karlsruhe, Germany \\ Correspondence to: Klaus-D. Gottschaldt (klaus-dirk.gottschaldt@dlr.de)
}

Received: 9 November 2016 - Discussion started: 28 November 2016

Revised: 8 March 2017 - Accepted: 21 March 2017 - Published: 16 May 2017

\begin{abstract}
We present in situ measurements of the trace gas composition of the upper tropospheric (UT) Asian summer monsoon anticyclone (ASMA) performed with the High Altitude and Long Range Research Aircraft (HALO) in the frame of the Earth System Model Validation (ESMVal) campaign. Air masses with enhanced $\mathrm{O}_{3}$ mixing ratios were encountered after entering the ASMA at its southern edge at about $150 \mathrm{hPa}$ on 18 September 2012. This is in contrast to the presumption that the anticyclone's interior is dominated by recently uplifted air with low $\mathrm{O}_{3}$ in the monsoon season. We also observed enhanced $\mathrm{CO}$ and $\mathrm{HCl}$ in the ASMA, which are tracers for boundary layer pollution and tropopause layer (TL) air or stratospheric in-mixing respectively. In addition, reactive nitrogen was enhanced in the ASMA. Along the HALO flight track across the ASMA boundary, strong gradients of these tracers separate anticyclonic from outside air.

Lagrangian trajectory calculations using HYSPLIT show that HALO sampled a filament of UT air three times, which included air masses uplifted from the lower or midtroposphere north of the Bay of Bengal. The trace gas gradients between UT and uplifted air masses were preserved during transport within a belt of streamlines fringing the central part of the anticyclone (fringe), but are smaller than the gradients across the ASMA boundary. Our data represent the first in situ observations across the southern part and downstream of the eastern ASMA flank. Back-trajectories starting at the flight track furthermore indicate that HALO transected the ASMA where it was just splitting into a Tibetan and an Iranian part. The $\mathrm{O}_{3}$-rich filament is diverted from the fringe
\end{abstract}

towards the interior of the original anticyclone, and is at least partially bound to become part of the new Iranian eddy.

A simulation with the ECHAM/MESSy Atmospheric Chemistry (EMAC) model is found to reproduce the observations reasonably well. It shows that $\mathrm{O}_{3}$-rich air is entrained by the outer streamlines of the anticyclone at its eastern flank. Back-trajectories and increased $\mathrm{HCl}$ mixing ratios indicate that the entrained air originates in the stratospherically influenced TL. Photochemical ageing of air masses in the ASMA additionally increases $\mathrm{O}_{3}$ in originally $\mathrm{O}_{3}$-poor, but $\mathrm{CO}$-rich air. Simulated monthly mean trace gas distributions show decreased $\mathrm{O}_{3}$ in the ASMA centre only at the $100 \mathrm{hPa}$ level in July and August, but at lower altitudes and in September the ASMA is dominated by increased $\mathrm{O}_{3}$. The combination of entrainment from the tropopause region, photochemistry and dynamical instabilities can explain the in situ observations, and might have a larger impact on the highly variable trace gas composition of the anticyclone than previously thought.

\section{Introduction}

The Earth System Model Validation (ESMVal) field experiment with the High Altitude and Long Range Research Aircraft (HALO, http://www.halo.dlr.de) was conducted during 10-24 September 2012 in close cooperation with the HALO TACTS mission (Jurkat et al., 2014; Vogel et al., 2015; Müller et al., 2016). During the 65 HALO flight hours of the ESMVal campaign, trace gas distributions were sampled from the ground to a maximum altitude of $15.3 \mathrm{~km}$ along 
the following route: Oberpfaffenhofen (Germany), Sal (Cape Verde), Cape Town (South Africa), boundary of Antarctica, Cape Town, Male (Maldives), Larnaca (Cyprus), Oberpfaffenhofen, Spitzbergen (Norway) and again to Oberpfaffenhofen. The goal was to gather in situ observations for the evaluation of Earth system models and to improve process understanding. Specific areas of interest included regions impacted by deep convection, lightning and biomass burning in West- and South Africa, anthropogenic pollution in Europe and the Mediterranean, the northern and southern polar regions, and the northern African and Asian monsoons.

The Asian summer monsoon (also known as Indian or south-west monsoon), sensu stricto, is a prevailing sea breeze, lasting from June to September (Gettelman et al., 2004; Lawrence and Lelieveld, 2010). Different mechanisms may contribute to the formation of a conduit of rising air, centred over the southern Tibetan Plateau (Bergman et al., 2013) during Northern Hemisphere summer. A high-pressure area forms in the convective detrainment altitudes, sustaining a coherent anticyclone, centred at 200 to $100 \mathrm{hPa}$ (Dunkerton, 1995; Randel and Park, 2006; Garny and Randel, 2016).

Polluted boundary layer air is entrained from throughout the region. It is effectively uplifted first in the narrow conduit to detrainment altitudes of about $200 \mathrm{hPa}$, later by largescale upward motion at the eastern side of the anticyclone and then confined by the Asian summer monsoon anticyclone (ASMA) (Lelieveld et al., 2001; Li et al., 2005; Randel and Park, 2006; Park et al., 2007, 2008, 2009; Chen et al., 2012; Bergman et al., 2013; Vogel et al., 2015; Ploeger et al., 2015). As a consequence, trace gas mixing ratios within the anticyclone are mainly shifted towards lower-tropospheric values, e.g. relatively increased carbon monoxide $(\mathrm{CO})$ ( $\mathrm{Li}$ et al., 2005; Park et al., 2008) and decreased ozone $\left(\mathrm{O}_{3}\right)$ (Randel and Park, 2006; Park et al., 2007, 2008; Kunze et al., 2010). The in situ measurements considered in our study also show enhanced $\mathrm{CO}$ mixing ratios in the ASMA, but instead of decreased $\mathrm{O}_{3}$ we found significantly increased $\mathrm{O}_{3}$ mixing ratios - relative to the UT air encountered south of the anticyclone.

While several studies looked into the boundary layer sources for ASMA air, entrainment of stratospheric or TL air has received much less attention. We are not aware of a study focusing on it, although the possibility of stratospheric entrainment at the eastern flank of the ASMA has already been recognised (Plumb, 2005; Randel and Park, 2006; Ren et al., 2014). Park et al. (2007) found a relatively high frequency of TL air at $100 \mathrm{hPa}$ (MLS satellite data, July-August 2005) at the eastern ASMA flank, and interpreted this as an indicator of frequent stratosphere-troposphere exchange. This is consistent with Konopka et al. (2010), who found that the ASMA enhances horizontal transport of $\mathrm{O}_{3}$-rich air from the extratropics into the stratospheric part of the tropical tropopause layer. Other studies (Cristofanelli et al., 2010; Barret et al., 2016) indicate the near absence of stratospheric intrusions during the monsoon season. At least the entrainment of $\mathrm{O}_{3}$-rich TL air is supported by the HALO ESMVal in situ observations considered here. Enhanced $\mathrm{O}_{3}$ was also found in CARIBIC (http://www.caribic-atmospheric.com) in situ measurements in the monsoon region. Trace gas signatures from the northern part of the ASMA were interpreted as photochemically older than those from the more central region, sampled at the southernmost parts of the CARIBIC flights (Baker et al., 2011; Rauthe-Schöch et al., 2016). However, the origin of enhanced $\mathrm{O}_{3}$ in the old air is not entirely clear, and Baker et al. (2011) also mentioned the possibility of stratospheric influences. Whether $\mathrm{O}_{3}$ in air originating in the ASMA is generally enhanced or depleted was pointed out as one of the major open questions related to the Asian monsoon already by Lawrence and Lelieveld (2010).

Here we present a unique set of upper troposphere (UT) in situ measurements in the ASMA, obtained during the HALO ESMVal campaign. The focus is on the measurements, their representation in a global chemistry climate simulation and the origin of air masses. We pinpoint the processes that led to the observed trace gas signatures using a more detailed analysis of an exemplary flight segment, and conclude showing how the present measurements could be reconciled with previous, seemingly contradictory studies. In a follow-up study the processes that determine the ASMA composition are further analysed by putting the HALO ESMVal measurements into a regional, seasonal and multi-annual perspective. We refer to that study (Gottschaldt et al., 2017) as accompanying paper in the following. The accompanying paper is mainly based on EMAC simulations, which also show that our in situ data reflect rather common processes in the ASMA. Both studies shall help to explain the highly variable composition of the ASMA and its outflow, addressing the following key aspects of the ASMA that were recently identified as poorly understood (Randel et al., 2016): dynamical and chemical coupling with convection, composition/reactive chemistry in the monsoon region, mixing of higher-latitude lower-stratospheric air into the tropical TL by the ASMA.

The paper is structured as follows: Sect. 2 provides a description of the instruments and techniques used for the in situ measurements of selected tracers during the ESMVal campaign, the Eulerian global chemistry climate simulation hindcasting the synoptic situation of the measurements, and the trajectory model. The transport pathways of air masses that contributed to the observed chemical composition and periods of interest from the measured time series are identified in Sect. 3. Section 4 shows that the EMAC global simulation may be used for the interpretation of the in situ measurements, because the main features are reproduced well. Section 5 is dedicated to the discussion of selected tracertracer relations in the in situ data. The eastern flank of the ASMA is found to be crucial for the generation of the observed trace gas signatures, which is discussed in Sect. 6 for that part of the flight providing the most direct observations of it. In Sect. 7 we reconcile the HALO ESMVal observations of increased $\mathrm{O}_{3}$ with previous studies that found de- 
creased $\mathrm{O}_{3}$ in the ASMA, and then conclude with a summary in Sect. 8.

\section{Methods}

\subsection{In situ measurement techniques}

All in situ data used in our analyses are based on a synchronised data set, created by merging the data with their individual time resolution to a common time axis with a resolution of $10 \mathrm{~s}$. This data set is available from the HALO database (https://halo-db.pa.op.dlr.de).

Carbon monoxide (CO) was measured with the threechannel quantum cascade laser infrared absorption spectrometer TRIHOP. CO data were sampled every $8 \mathrm{~s}$ with an integration time of $1.5 \mathrm{~s}$ and a total $1 \sigma$ uncertainty of $1.8 \mathrm{nmol} \mathrm{mol}^{-1}$ (Schiller et al., 2008; Müller et al., 2016).

A newly designed atmospheric chemical ionisation mass spectrometer (AIMS) with an electrical discharge source and in-flight calibration provided $\mathrm{HCl}$ mixing ratios with a $1 \sigma$ detection limit of $10-15 \mathrm{pmol} \mathrm{mol}^{-1}$ and an accuracy of $12 \%$ (Jurkat et al., 2014, 2016; Voigt et al., 2014). AIMS measurements compared well in general to remote sensing techniques on board HALO, like the Gimballed Limb Observer for Radiance Imaging of the Atmosphere - GLORIA (Ungermann et al., 2015).

Total reactive nitrogen, $\mathrm{NO}_{y}$, is the sum of all reactive nitrogen species in the atmosphere. Besides $\mathrm{NO}_{x}(=$ $\mathrm{NO}+\mathrm{NO}_{2}$ ), $\mathrm{HNO}_{3}$, peroxyacetyl nitrate (PAN), HONO, $\mathrm{N}_{2} \mathrm{O}_{5}, \mathrm{HO}_{2} \mathrm{NO}_{2}, \mathrm{NO}_{3}$ are the most abundant species of the odd nitrogen family. $\mathrm{NO}$ and $\mathrm{NO}_{y}$ were measured during the ESMVal campaign by the AtmosphEric Nitrogen oxides mEAsurement System (AENEAS) - a two-channel NOchemiluminescence detector in combination with a gold converter installed in one channel (Ziereis et al., 2000). The detection limit is about $8 \mathrm{pmol} \mathrm{mol}^{-1}$ for an integration time of $1 \mathrm{~s}$. Its overall uncertainty is about $8 \%(6.5 \%)$ for volume mixing ratios of $0.5 \mathrm{nmol} \mathrm{mol}^{-1}\left(1 \mathrm{nmol} \mathrm{mol}^{-1}\right)$.

The Fast Airborne Ozone instrument (FAIRO) deployed during the ESMVal campaign is based on a chemiluminescence sensor plus an UV photometer (Zahn et al., 2012), achieving at least an accuracy of $1.5 \%$ at $10 \mathrm{~Hz}$.

\subsection{Atmospheric dynamics and chemistry simulations}

The Eulerian simulation used for this study was performed with the EMAC model (Jöckel et al., 2010) within the project Earth System Chemistry integrated Modelling (ESCiMo), as a German contribution to the Chemistry Climate Model Initiative (CCMI). This simulation has been described and evaluated in detail by Jöckel et al. (2016) as RC1SD-base-10a. Its set-up is based on the CCMI transient hindcast reference simulation in specified dynamics mode (Eyring et al., 2013). Here we just refer to it as the "simulation". Key characteristics of the simulation are a representation of the global do- main, with a spherical truncation of T42 and 90 vertical hybrid pressure levels up to $0.01 \mathrm{hPa}$, and a nudging of dynamics towards ERA-Interim reanalyses data (Dee et al., 2011) from the free troposphere to a pressure altitude of $10 \mathrm{hPa}$. The simulation also includes complex interactive chemistry with online feedback on dynamics. This set-up reproduces the synoptic situation during the aircraft campaign (ESMVal and all other campaigns of the simulated period), allowing direct comparisons of simulated and measured data. In particular, it was shown by Nützel et al. (2016) that the climatological representation of key dynamical features of the ASMA in ERA-Interim is in line with most other reanalysis data sets. However, some processes cannot be explicitly resolved on the coarse grid of the global simulation. These subgrid-scale processes are accounted for by parameterisations that are expected to reproduce climatological characteristics rather than individual events. This pertains in particular to convection and convective transport, thereby negatively affecting the non-climatological comparability of simulated versus observed atmospheric trace gas mixing ratios (Tost et al., 2010). Global fields are output with a frequency of $10 \mathrm{~h}$, but data along the HALO flight track were sampled with the model time step resolution of $12 \mathrm{~min}$ (see description of S4D by Jöckel et al., 2010). In addition to the nitrogen oxides listed in Sect. 2.1, the EMAC tracers $\mathrm{NHOH}$, $\mathrm{HNO}, \mathrm{NH}_{2} \mathrm{O}$ and $\mathrm{NH}_{2} \mathrm{OH}$ are also included in simulated $\mathrm{NO}_{y}$. It is calculated as the mixing ratio of nitrogen atoms in the sum of the listed $\mathrm{NO}_{y}$ compounds, which is consistent with what is measured by the corresponding in situ instrument. Net photochemical $\mathrm{O}_{3}$ production rates are calculated from the diagnostic tracers ProdO3 and LossO3 (Jöckel et al., 2016). Unless stated otherwise, the tropopause is diagnosed in our EMAC simulations according to the WMO definition between $30^{\circ} \mathrm{S}$ and $30^{\circ} \mathrm{N}$, and by $\mathrm{PV}=3.5 \mathrm{PVU}$ elsewhere (Jöckel et al., 2006).

\subsection{Lagrangian trajectory calculations}

The HYbrid Single-Particle Lagrangian Integrated Trajectory (HYSPLIT) model (Draxler and Hess, 1998; Draxler and Rolph, 2015) was used to calculate backwardtrajectories, starting at the flight track. The same starting time is used for all back-trajectories of the selected flight segment; i.e. the time lag between different positions along the track is neglected. Thus smaller flight segments need to be chosen if the wind fields are more dynamic. HYSPLIT is driven kinematically, by meteorological fields of the Global Data Assimilation System (GDAS), in $1^{\circ} \times 1^{\circ}$ horizontal resolution, 23 vertical levels between 1000 and $20 \mathrm{hPa}$, as provided by NCEP (National Weather Service's National Centers for Environmental Prediction, http://ready.arl.noaa.gov/ gdas1.php) at $3 \mathrm{~h}$ time steps. Convection is represented indirectly, as smoothed vertical velocity components in the reanalysis fields. HYSPLIT trajectories only capture advection and stirring. Note that, in contrast, EMAC captures convec- 

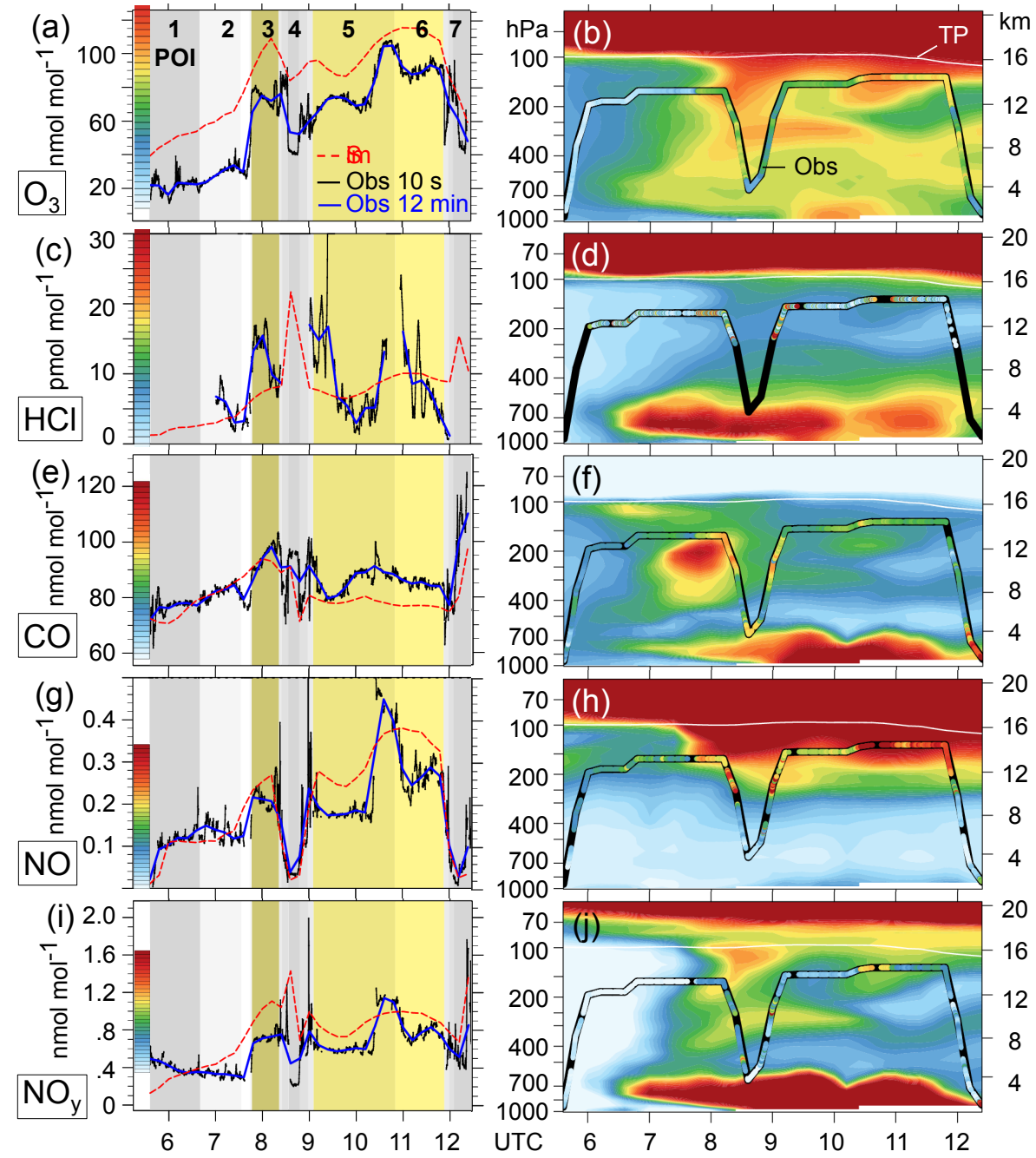

Figure 1. The left panel shows mixing ratios of $\mathrm{O}_{3}, \mathrm{HCl}, \mathrm{CO}, \mathrm{NO}$ and $\mathrm{NO}_{y}$ along the HALO flight track from Male to Larnaca on 18 September 2012. Black: in situ measurements in 10 s resolution, Blue: interval averages of the in situ data, corresponding to 12 min simulation time steps, Red: simulation results. Yellow shadings mark the periods of interest, see text. Corresponding curtains simulated with EMAC along the flight track are shown on the right. The pipe follows the HALO flight altitude, filled with measured trace gas mixing ratios in the same colour coding (legends integrated in corresponding left panels). Black = missing. A thin white line indicates the simulated tropopause.

tion directly (although parameterised), as well as mixing in the form of diffusion (Roeckner et al., 2006).

\section{Air masses observed and transport pathways}

An air mass with enhanced mixing ratios of $\mathrm{O}_{3}, \mathrm{CO}, \mathrm{NO}$, $\mathrm{NO}_{y}$ and $\mathrm{HCl}$ (Fig. 1) was sampled during a flight on 18 September 2012 from the Maldives to Cyprus over the Arabian Sea. Here, HALO flew at an altitude of 160 to $170 \mathrm{hPa}$, just before reaching the Oman coast (Fig. 2). We attribute the sudden increase of the above-mentioned trace gases at 07:46 UTC to entering the ASMA from the south. The sampling of this air mass was interrupted by a dive to probe the lower boundary of the ASMA, but after that HALO continued to fly in UT air related to the ASMA.

We divide the ESMVal-flight from Male to Larnaca pragmatically into seven parts (Table 1), called periods of interest (POI) in the following. Thereby we refer to the central region as the "interior", and to the boundary region, i.e. the outer streamlines of the ASMA circulation, as the "fringe". The terms "interior" and "fringe" characterise actual positions of streamlines within the anticyclone, independent of the trace gas signatures they carry. Streamlines represent an instantaneous snapshot of transport barriers, because there is no large-scale transport perpendicular to streamlines. Figure 3 illustrates the evolution of the ASMA circulation at flight altitude from 9 days before to 1 day after our measurements. Besides streamlines, Fig. 3 shows geopotential height, be- 

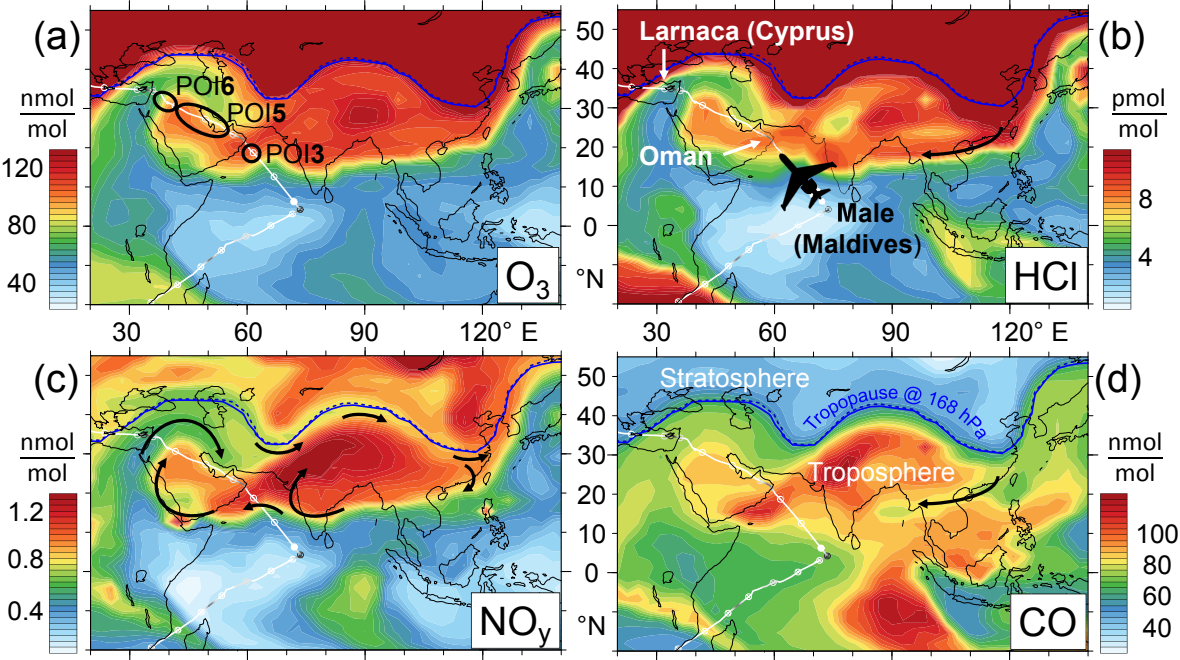

Figure 2. Mixing ratios of $\mathrm{O}_{3}, \mathrm{HCl}, \mathrm{NO}_{y}$ and $\mathrm{CO}$, as simulated by EMAC for 06:00 UTC on 18 September 2012, at 168 hPa. Beads along the flight track are separated by $1 \mathrm{~h}$, and the tail end of the HALO silhouette marks the actual position. Black circles in panel (a) indicate the HALO position during the periods of interest, which represent the ASMA measurements. During POI3 HALO was flying in an altitude range containing the shown pressure level. Arrows illustrate the wind field (c) and also highlight a filament of TP layer entrainment into the free troposphere at the eastern ASMA flank, indicated by anti-correlated mixing ratios of $\mathrm{HCl}$ and $\mathrm{CO}$ (b and d).

Table 1. Periods of interest for the measurements during the HALO ESMVal flight from Male to Larnaca on 18 September 2012. Column UTC shows the time periods of the measurements, figure lists the corresponding trajectory figures.

\begin{tabular}{|c|c|c|c|c|}
\hline & Classification & UTC & Remarks & Fig. \\
\hline POI1 & $\begin{array}{l}\text { Ascent from Male }+ \\
\text { UT south of ASMA }\end{array}$ & $\begin{array}{l}05: 36 \\
06: 40\end{array}$ & Clean air, not related to ASMA & - \\
\hline POI2 & $\begin{array}{l}\text { Southern ASMA } \\
\text { boundary region }\end{array}$ & $\begin{array}{l}06: 40 \\
07: 46\end{array}$ & Back-trajectories related to ASMA, but clean air dominates & A1 \\
\hline POI3 & $\begin{array}{l}\text { Outer ASMA } \\
\text { streamlines }\end{array}$ & $\begin{array}{l}07: 46 \\
08: 21\end{array}$ & $\begin{array}{l}\text { UT ASMA circulation }+ \text { air uplifted at eastern flank; } 3 \text { days after } \\
\text { passing eastern flank }\end{array}$ & $3, \mathrm{~A} 2, \mathrm{~S} 5$ \\
\hline POI4 & $\begin{array}{l}\text { Dive over Arabian } \\
\text { Peninsula }\end{array}$ & $\begin{array}{l}08: 21 \\
09: 05\end{array}$ & lower ASMA boundary $(\sim 180 \mathrm{hPa})$ to $650 \mathrm{hPa}$ & A3 \\
\hline POI5 & $\begin{array}{l}\text { Outer ASMA } \\
\text { streamlines }\end{array}$ & $\begin{array}{l}09: 05 \\
10: 50\end{array}$ & As POI3, but filament curled in; 6 days after passing eastern flank & A4 \\
\hline POI6 & $\begin{array}{l}\text { Outer ASMA } \\
\text { streamlines }\end{array}$ & $\begin{array}{l}10: 50 \\
11: 53\end{array}$ & As POI3, but less uplifted air; 5 days after passing eastern flank & A5 \\
\hline POI7 & Descent into Larnaca & $\begin{array}{l}11: 52 \\
12: 29\end{array}$ & Lower ASMA boundary to ground & A6 \\
\hline
\end{tabular}

cause increased geopotential is a proxy for characterising the extent of the ASMA on pressure levels (Barret et al., 2016). Alternatively, PV has been proposed to delineate the ASMA in isentropic coordinates (Ploeger et al., 2015) and the corresponding equivalent to Fig. 3 is provided in the Supplement S1. However, the above ASMA boundary definitions (Ploeger et al., 2015; Barret et al., 2016) and another one based on maximal wind speed, used by Pan et al. (2016), emphasise concepts of a closed ASMA volume or transport barriers on monthly or seasonal timescales. In contrast, our analyses rather aim to explain observed UT tracer distributions resulting from daily-scale dynamics. The latter is best captured by Lagrangian trajectories, which unlike the above Eulerian approaches inherently reflect the time dependence of the flow. Our choice of POIs and the delineation of the ASMA are thus based on back-trajectories from the flight path and the observed trace gas signatures. 


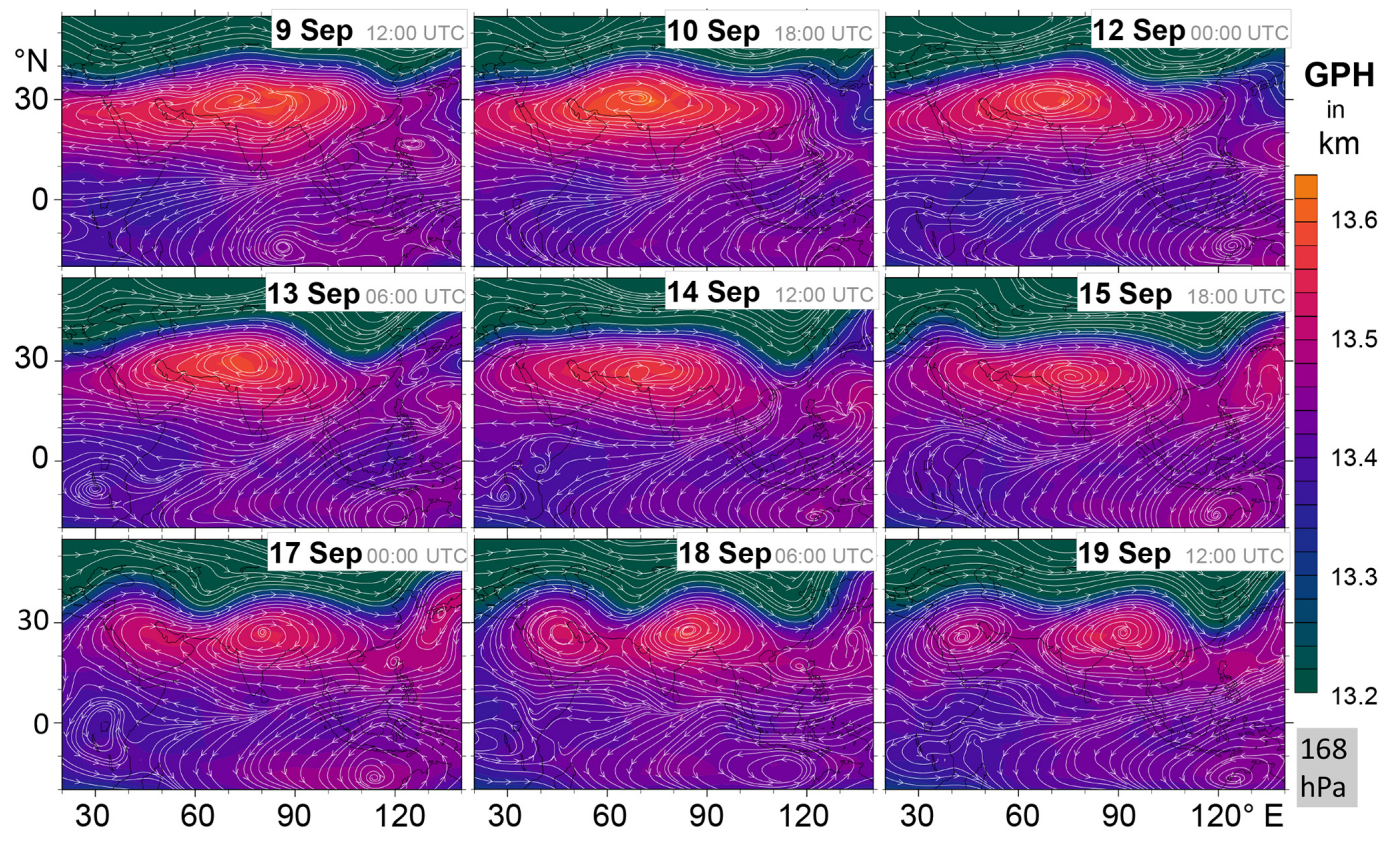

Figure 3. Streamlines and geopotential height (GPH) at the $168 \mathrm{hPa}$ pressure level as simulated by EMAC for selected output time steps in September 2012.

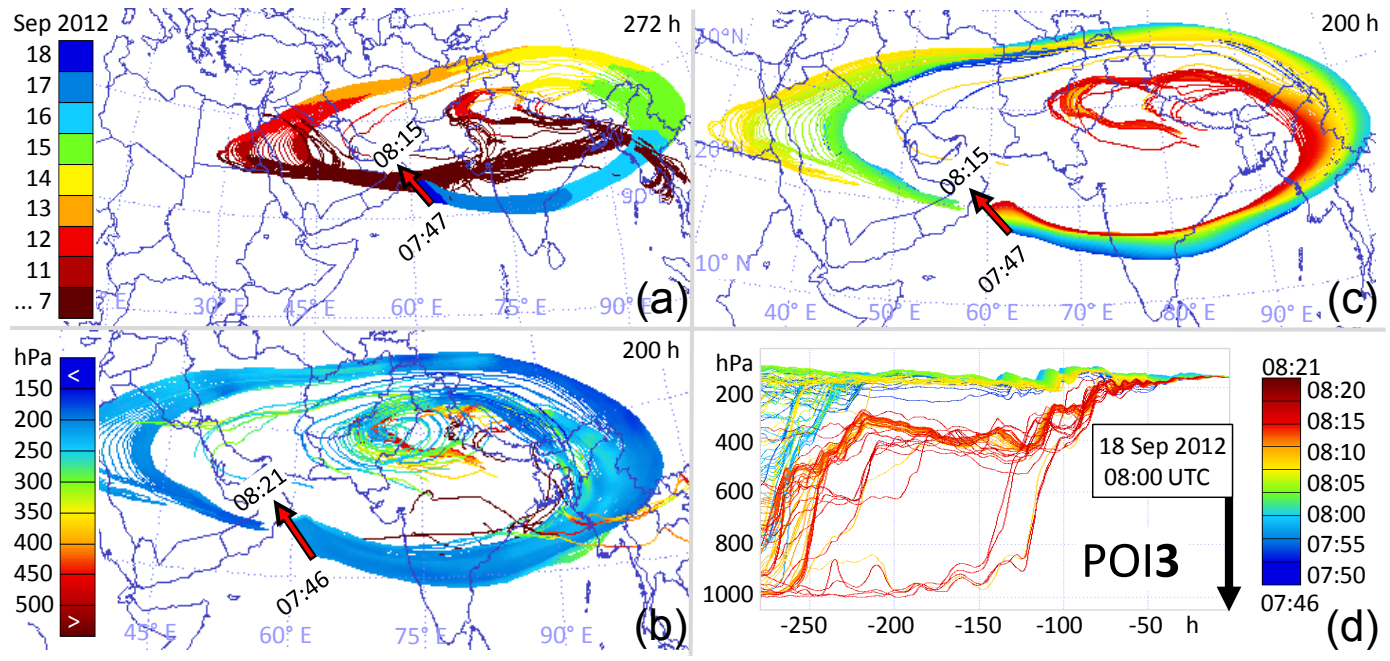

Figure 4. HYSPLIT-simulated backward trajectories starting at the HALO flight track (red arrows). The integration length is noted in the upper-right corner of each lat-lon panel. All trajectories of one panel start at the same time, approximately in the middle of the period corresponding to the respective flight segments (d). Colours in panel a relate the previous positions of the measured air parcels to calendar days. Colours in (b) show pressure altitude, which is supplemented by altitude vs. time in (d). Individual trajectories are colour coded according to the time of measurement at their respective starting positions in (c) and (d). Panels a show the same map section here and throughout Appendix A, while all other panels are scaled individually.

Clearly ASMA-related air masses (POI3/5/6) are marked in shades of yellow in the left column of Fig. 1, and indicated by three black ovals in Fig. 2a. For the sake of brevity we focus on POI3 in the following, while more information about the other flight segments is available in Appendix A.
The flight segment POI3 is characterised by almost parallel back-trajectories along the southern ASMA fringe (Fig. 4c). The outer trajectories show air masses circling around the ASMA within 10 days (Fig. 4a) at $160-170 \mathrm{hPa}$ (Fig. 4b), while the inner trajectories were first uplifted at the southern/south-western flanks of the Himalayas, then the Ti- 
betan conduit to merge with the UT ASMA circulation at its eastern flank (Fig. 4d). The back-trajectories of POI3 mainly encompass South Asia and the Arabian Peninsula. We define the start of $\mathrm{POI} 3$ by a sudden increase of $\mathrm{O}_{3}, \mathrm{CO}, \mathrm{HCl}$ and nitrogen oxide mixing ratios, compared to the clean air encountered before (POI2). The transition from POI2 to POI3 is not clearly reflected in the back-trajectories, because the northernmost back-trajectories of POI2 resemble the adjoining, southernmost back-trajectories of POI3 (see Appendix A, Fig. A1). We consider this to be an artefact of very dynamic wind fields that are not well represented in the trajectory calculations (see also discussion of POI2 in Appendix A). The problem is most likely related to the combination of the rapidly splitting ASMA (Fig. 3) and the strongly divergent flow at the eastern ASMA boundary (Fig. A2), where the southbound ASMA circulation separates from the eastward subtropical jet. POI3 ended when HALO started to descend for a dive over Oman. Almost immediately below the flight altitude of POI3 the back-trajectories no longer clearly indicate direct transport of air from the eastern ASMA flank.

During POI 3 the fringe was transected from the outer to the inner streamlines. Deep convection at the eastern ASMA flank contributed considerably to POI5 (Fig. A4d), and very little to POI6 (Fig. A5d). POI3 passed the eastern ASMA flank on 15 September (Fig. 4a), POI5 on 12 September (Fig. A4a), POI6 on 13 September 2012 (Fig. A5a). Note that the eastern ASMA flank moved eastward during that period, and the area enclosed by the back-trajectories did shrink (Figs. 3, 4a, A4a, A5a). A schematic of the synoptic situation for POI3/5/6 is given in Fig. 5. All three POIs are part of a filament that spent at least 10 days in the UT of the ASMA region, and was entrained by updraughts at the eastern ASMA flank. The curled-in structure of the filament indicates that the ASMA split into a Tibetan and an Iranian part around 18 September 2012 (Fig. 3). It is not clear whether the steep $\mathrm{O}_{3}$ gradient, chosen as the beginning of $\mathrm{POI} 3$, corresponds to where outside flow later separates from the ASMA circulation. Thus we do not attempt to estimate whether or how much outside air becomes part of the ASMA circulation by entrainment at the southern edge. This uncertainty is not important for the present study, but might need to be addressed before quantitatively estimating trace gas budgets within the ASMA.

Six-hourly satellite images show no signs of fresh convection in the vicinity of the HALO track on the days before the flight, in contrast to the eastern ASMA edge and the Himalayas (see Supplement Fig. S8). Shorter-lived, localised convective events were identified in 15 min satellite images (not shown) over the Hajar mountains (Oman) and east of the Strait of Hormuz on 17 and 18 September 2012, afternoon. We set a more detailed discussion of this aspect aside here, since dispersion calculations (not shown) indicate that the UT ASMA measurements during the ESMVal campaign (POI3/5/6) were not affected by those convective plumes. Furthermore, videos from the cockpit camera show

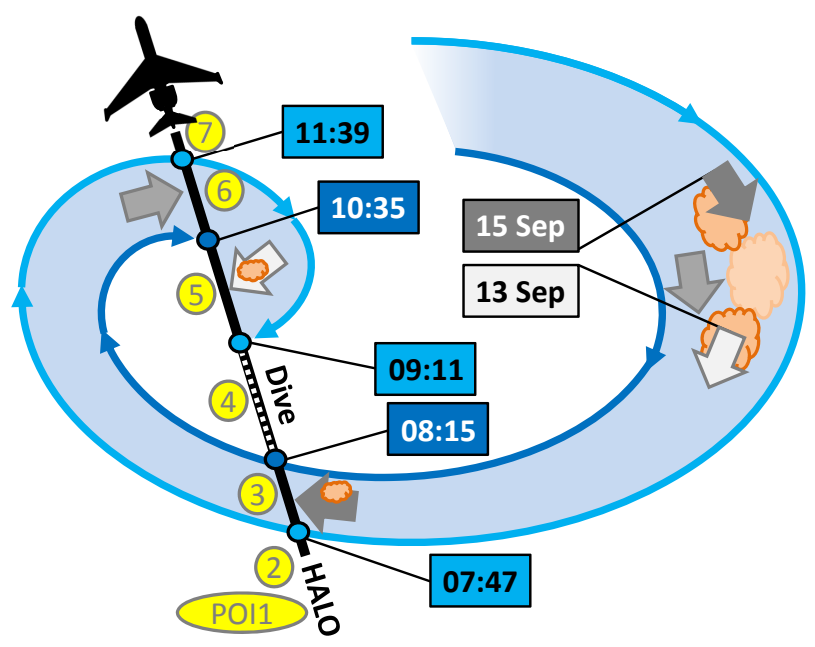

Figure 5. Schematic of the filament of UT ASMA air that was transected by HALO during the ESMVal campaign. The encountered air parcels all had a similar genesis: UT air travelling in the ASMA fringe was to different degrees entrained by deep convection at the eastern ASMA flank, then continuing along the southern flank of the anticyclone to the respective measurement locations. POI3 provides the most direct view of the eastern ASMA flank. The schematic is in ASMA centred coordinates, with relative positions of air masses (grey arrows) and convection (orange clouds) indicated. The interior trajectory of the filament and corresponding times of measurement are indicated by dark blue and the exterior trajectory is light blue. Grey shades and white indicate the air masses encountered during the respective three periods of interest (POI3/5/6), and to the corresponding date they passed the eastern flank.

that HALO did not transect the convective region over the Hajar mountains on 18 September 2012.

POI3 is less affected by stirring during transport from the eastern ASMA flank to the measurement location than POI5/6 and thus provides a more direct view of the remote and so far unsampled eastern flank. In addition to stirring, diffusion may also act to conceal features of trace gas distributions during transport. However, assuming a diffusion coefficient of $15 \mathrm{~m}^{2} \mathrm{~s}^{-1}$ (Schumann et al., 1995), purely diffusive mixing is negligible here. It acts on a scale of about $1 \mathrm{~km}$ per day, and air parcels needed less than a week from the eastern flank to their respective measurement locations (Figs. 4a, $\mathrm{A} 4 \mathrm{a}, \mathrm{A} 5 \mathrm{a})$. For comparison, two measurement points in $10 \mathrm{~s}$ time resolution at typical HALO speed are about $2.5 \mathrm{~km}$ apart.

\section{Representation of the in situ measurements in EMAC}

Here we discuss to what extent the aforementioned (Sect. 2.2) simulation with the EMAC model can reproduce the $\mathrm{O}_{3}, \mathrm{HCl}, \mathrm{CO}, \mathrm{NO}$ and $\mathrm{NO}_{y}$ measurements in order to use that simulation for further interpretation of the measurements. 
The EMAC simulation has a horizontal grid resolution of about $300 \mathrm{~km}$ in the ASMA region, and the time step length is $12 \mathrm{~min}$. Processes acting on smaller, unresolved scales need to be parameterised. This is compared to in situ data with a time resolution of $10 \mathrm{~s}$, corresponding to a spacing of about $2.5 \mathrm{~km}$. Due to the different resolutions, a perfect match between the simulation and observations cannot be expected. Additional differences might be caused by non-perfect representations of emissions, physical and chemical processes.

EMAC in the set-up used here is known to simulate a high $\mathrm{O}_{3}$ bias in the tropics, more specifically of $5-25 \%$ at 100 $250 \mathrm{hPa}$, compared to ozonesonde data, and $30-50 \%$ in the tropospheric column compared to satellite data (Jöckel et al., 2016). However, the relative enhancement observed during the POIs is reproduced by the simulation (Fig. 1a).

The $\mathrm{HCl}$ mixing ratios encountered during the flight from Male to Larnaca were at the detection limit of the AIMS instrument; therefore they had enhanced noise. They were interrupted by missing value periods due to calibrations and background measurements. In order to carve out variations on a timescale relevant for this study, we smoothed the $\mathrm{HCl}$ in situ data as follows: each original value of the time series is substituted by the average of two means - the mean of all values $150 \mathrm{~s}$ before and the mean $150 \mathrm{~s}$ after the original value. Missing values are ignored for calculating the mean, but the average is missing if at least one missing value is present. Each operation is based on equal weights. This procedure gives values in periods of sparse data greater weight, but was found to preserve the shape of the time series better than a conventional running mean filter. Note that the time series technically is still in $10 \mathrm{~s}$ resolution after the smoothing, but with regard to contents, time resolution has been traded for a better signal-to-noise ratio. In situ measurements in the subtropical UTLS over North America (Marcy et al., 2004) indicate that UT background mixing ratios of $\mathrm{HCl}$ may be of the order of $5 \mathrm{pmol} \mathrm{mol}^{-1}$. Such low values are found in our data (Fig. 1c) during clean-air-dominated POI2 and in the middle of POI5, where back-trajectories point to lowertropospheric air (Fig. A4c, d). Relative $\mathrm{HCl}$ enhancements in other sections of the flight are also clearly visible in Fig. 1c, indicating in-mixing of stratospheric or TL air. The simulation reproduces the magnitude of measured $\mathrm{HCl}$ and also the rough time evolution during the POIs. We consider the agreement as reasonable, given the uncertainties of the measurements, as well as the possibility of spurious washing out and slightly misrepresented gradients of trace gas mixing ratios (Figs. 1d, 2b) in the simulation. The relative minimum in free tropospheric $\mathrm{HCl}$ is best seen in the curtain (Fig. 1d), together with a filament of increased $\mathrm{HCl}$ extending from the tropopause to the flight track around 08:00 UTC.

Considering the use of monthly instead of daily resolved biomass burning emission data, there is a surprisingly good agreement between measured and simulated $\mathrm{CO}$. The air masses encountered during the measurements might have experienced sufficient mixing since last boundary layer contact to lose memory of any high-frequency emission variations, making monthly emissions in the simulation a viable approximation here. There is a negative bias of simulated $\mathrm{CO}$ of about $10 \mathrm{nmol} \mathrm{mol}^{-1}$ during POI5/6 (Fig. 1e). Figure $2 \mathrm{~d}$ shows that POI5/6 coincide with a region of strong $\mathrm{CO}$ gradients. This may result in some inaccuracies in the simulated values along the flight path, even if the synoptic situation is captured well by the simulation. Uncertainties in the chemical mechanism also have the potential to cause a low bias of $\mathrm{CO}$ and a high bias of $\mathrm{O}_{3}$ (Gottschaldt et al., 2013; Righi et al., 2015). In any case, caution is needed when interpreting those measurements based on the simulation. We focus on the best represented flight section (POI3) whenever possible.

The relative changes of observed $\mathrm{NO}_{y}$ (Fig. 1i, j) and $\mathrm{NO}$ (Fig. 1g, h) mixing ratios are captured by the simulation, in particular the enhancements of those trace gases in the ASMA. However, observed short timescale variations during POI5/6 are smoothed out in the simulated data because of the coarser temporal resolution of the output (direct) and the representation of processes is limited by the grid resolution (indirect). The representation of nitrogen oxides in the simulation also depends on the quality of the corresponding emission inventories, and is further complicated by the shorter photochemical lifetime compared to $\mathrm{CO}$ and $\mathrm{O}_{3}$. $\mathrm{NO}-$ and to a lesser degree also $\mathrm{NO}_{y}$ - mixing ratios have steep vertical gradients at the flight altitude during POI5/6 (Fig. 1h, j). We do not expect a global simulation to perfectly reproduce the time and location of such features, and the corresponding inaccuracies are most likely to print through in the vicinity of steep gradients. Also, parameterisations of subgrid-scale processes are mainly designed to reproduce climatological characteristics and individual convective events in the simulation may not be triggered at the same times and locations as in reality. There are regions of over- and underestimated NO and $\mathrm{NO}_{y}$ respectively, and we don't expect any systematic bias in the representation of nitrogen oxides in the simulation. In particular, we note that the magnitude of measured NO mixing ratios is reproduced by the simulation, despite most UT $\mathrm{NO}_{x}$ in the ASMA being produced by lightning (see accompanying paper for details) and estimates of lightning $\mathrm{NO}_{x}$ emissions include large uncertainties (Schumann and Huntrieser, 2007).

To summarise, the limited resolution of the simulation is at the core of most of the deviations between observed and simulated trace gas mixing ratios. This means that, in return, a large-scale feature like the ASMA is likely to be represented well by the specified dynamics simulation set-up, which is also well suited to reproduce the corresponding trace gas distributions. Overall, we are confident that the simulation reproduces the atmospheric situation well enough to be utilised for interpreting the in situ data of the POIs. The overall agreement between observed and simulated data is best for POI3. 


\section{Tracer-tracer relations}

Enhanced tropospheric tracers $(\mathrm{CO})$ fit the climatological picture of the ASMA, but at the same time enhanced $\mathrm{O}_{3}$ and $\mathrm{HCl}$ is notable and indicate enhanced in situ production, or contributions of stratospherically affected air, e.g. from the TL. In this section we determine the origins of the measured trace gas signatures with the help of tracer relations. The following analysis focuses on $\mathrm{CO}$ vs. $\mathrm{O}_{3}$, and is supplemented by other relations ( $\mathrm{HCl}$ vs. $\mathrm{O}_{3}, \mathrm{NO}$ vs. $\mathrm{O}_{3}, \mathrm{NO}_{x}$ vs. $\mathrm{O}_{3}, \mathrm{NO}_{x}$ vs. $\mathrm{NO}_{y}$ ). POI3, POI5 and POI6 are part of one filament, and all are characterised by mixing of UT air with uplifted lower-tropospheric air at the eastern ASMA flank (Fig. 5). In the following, we exemplify tracer-tracer relations in the filament by a discussion of POI3. We focus on that period, because it is best represented in the simulation and the dynamics are less complicated than for POI5 and POI6. The latter means that POI3 provides the most direct view of the eastern flank and the relevant processes of that key region are least concealed by stirring. Furthermore, the air encountered during POI5/6 has more remote source regions (Figs. A4a, A5a) and was subject to longer transport since passing the eastern ASMA flank. Thus, it is easier to disentangle the relevant processes for $\mathrm{POI} 3$.

\subsection{Mixing of different reservoirs during POI3}

All measurements from 07:47 to 08:15 UTC (dots) lay on one mixing line in the $\mathrm{CO}$ vs. $\mathrm{O}_{3}$ plot for POI3 (Fig. 6a). It connects a $\mathrm{CO}$-poor \& $\mathrm{O}_{3}$-rich reservoir $\left(\mathrm{CO} \downarrow \uparrow \mathrm{O}_{3}\right)$ with a CO-rich \& $\mathrm{O}_{3}$-poor reservoir $\left(\mathrm{CO} \uparrow \downarrow \mathrm{O}_{3}\right)$. The "\&" notation is used in the following to express "and at the same time". Rich and poor are meant relative to the ranges observed during that flight section. Park et al. (2007) proposed thresholds of $\mathrm{CO}>60 \mathrm{nmol} \mathrm{mol}^{-1}$ and $\mathrm{O}_{3}<300 \mathrm{nmol} \mathrm{mol}^{-1}$ to characterise tropospheric air in the ASMA. According to that criterion, absolute mixing ratios of POI3 are completely tropospheric. However, the lowest $\mathrm{O}_{3}$ mixing ratios in POI3 (about $68 \mathrm{nmol} \mathrm{mol}^{-1}$ ) still represent a significant enhancement with respect to $30 \mathrm{nmol} \mathrm{mol}^{-1}$ at the end of POI2 and also compared to $40 \mathrm{nmol} \mathrm{mol}^{-1}$ encountered below the ASMA during POI4 (Fig. 1a). The term reservoir is used here for the current state rather than for hypothetical end members. The negative slope indicates either an ozonedepleting photochemical regime (Baker et al., 2011), or that both reservoirs have seen different stratospheric or TL influences. The latter is supported by relatively enhanced $\mathrm{HCl}$ mixing ratios in $\mathrm{CO} \downarrow \uparrow \mathrm{O}_{3}$ and accordingly depleted $\mathrm{HCl}$ at the end of $\mathrm{CO} \uparrow \downarrow \mathrm{O}_{3}$ (Fig. 6c). A positive correlation between $\mathrm{O}_{3}$ and $\mathrm{HCl}$ inside the ASMA has also been found by Park et al. (2008), based on ACE-FTS satellite data, and attributed to a common stratospheric origin of both species. The negative correlation between $\mathrm{CO}$ and $\mathrm{O}_{3}$ in the ESMVal in situ data is consistent with MLS observations in the ASMA region (at
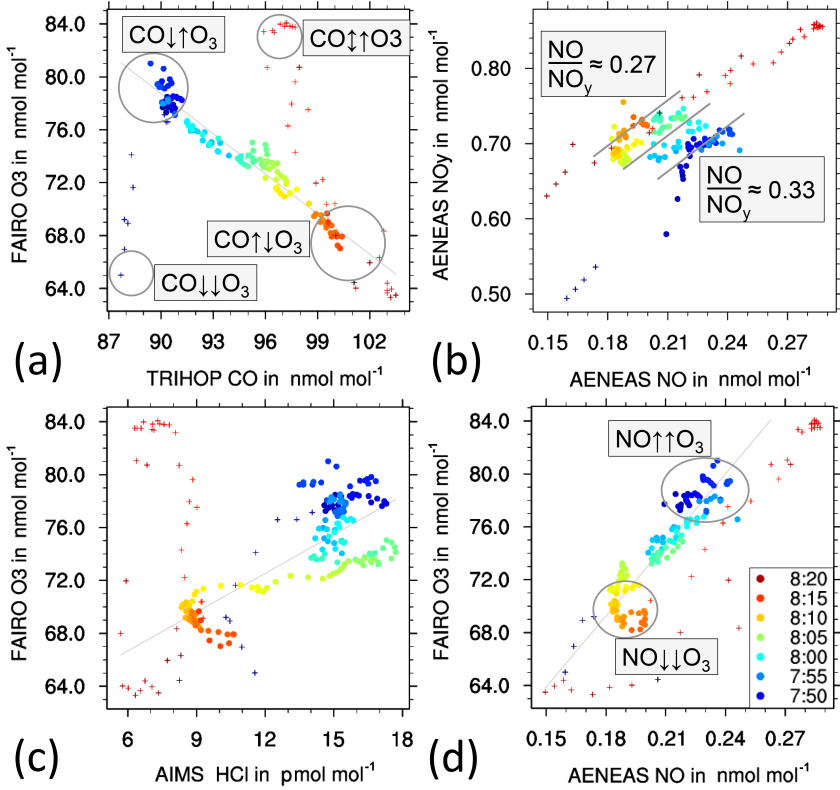

Figure 6. Tracer-tracer relations, as observed during one transect through the ASMA fringe. Colours indicate the time of measurement, filled circles highlight the first period of interest (POI3), grey lines are linear fits to those data (a, $\mathbf{c}, \mathbf{d})$ or hand-drawn markings discussed in the text (b), and crosses show data just before and after POI3. Reservoirs referred to in the text are marked by grey boxes.

$215 \mathrm{hPa}$ ), which cover several complete years (Livesey et al., 2013).

According to Fig. 4a, b, c, d, trajectories carrying signature $\mathrm{CO} \downarrow \uparrow \mathrm{O}_{3}$ make up the outer fringe of the ASMA, travelling along almost closed streamlines at an altitude of about $160 \mathrm{hPa}$, which is in the tropopause region on the northern flank, and well within the troposphere on the southern flank of the ASMA. The inner (with respect to ASMA) streamlines of the filament are dominated by signature $\mathrm{CO} \uparrow \downarrow \mathrm{O}_{3}$. The corresponding back-trajectories indicate air masses uplifted from the boundary layer at the southern flanks of the Himalayas, and mid-tropospheric air uplifted over the southwestern flanks of the Himalayas. Both meet at about $300 \mathrm{hPa}$ over the Tibetan Plateau, to be further uplifted to the UT, and merged with the anticyclone at its eastern flank. The line connecting $\mathrm{CO} \downarrow \uparrow \mathrm{O}_{3}$ and $\mathrm{CO} \uparrow \downarrow \mathrm{O}_{3}$ forms a linear correlation with a correlation coefficient of $r=0.97$. This is very compact, indicating homogenous reservoirs. Freshly uplifted air did not seem to carry much small-scale heterogeneity through the Tibetan conduit. This might explain that the simulation results compared rather well for this flight segment, because small-scale differences between real and simulated (inventory) biomass burning could not print through to UT trace gas signatures. Independently of that, UT lightning $\mathrm{NO}_{x}$ emissions still introduce differences between simulated and observed trace gas mixing ratios in the ASMA. Feeding of the inner trajectories of the filament through the Tibetan 
conduit defines reservoir $\mathrm{CO} \uparrow \downarrow \mathrm{O}_{3}$. Reservoir $\mathrm{CO} \downarrow \uparrow \mathrm{O}_{3}$ is air circling in the ASMA fringe in the UT. The mixing situation, as it occurred at the eastern ASMA flank, is carried by almost parallel streamlines to where it was encountered by HALO (Fig. 4c). Furthermore, shearing has been small in the air mass considered here, as indicated by little differential velocities (Fig. 4a). The strong correlation of the measurement time stamp (corresponding to the radial position in the fringe) with the location of the corresponding data in $\mathrm{CO}$ vs. $\mathrm{O}_{3}$ space is also indicative of almost parallel streamlines.

\subsection{Processes reflected by nitrogen oxides during POI3}

Consider the hypothetical case of a fixed $\mathrm{NO} / \mathrm{NO}_{y}$ partitioning (ratio): variations of $\mathrm{NO}$ and $\mathrm{NO}_{y}$ mixing ratios are reflected by positive slopes in $\mathrm{NO}$ vs. $\mathrm{NO}_{y}$ space. Neighbouring measurements indeed seem to lie on multiple parallel lines corresponding to $\mathrm{NO}$ proportional to $\mathrm{NO}_{y}$ (indicated by grey lines connecting consecutive times/colours in Fig. 6b). Different lines correspond to different $\mathrm{NO} / \mathrm{NO}_{y}$ ratios. The observed $\mathrm{NO} / \mathrm{NO}_{y}$ ratio decreases from about 0.33 in the outer streamlines of the filament (blueish dots throughout Fig. 6), to about 0.27 (reddish dots) at the end of POI1. As long as nitrogen species are not removed from the atmosphere, for example by rainout or washout, photochemical processes tend to convert $\mathrm{NO}$ to other $\mathrm{NO}_{y}$ species and therefore change the $\mathrm{NO} / \mathrm{NO}_{y}$ ratio. Concurrently $\mathrm{O}_{3}$ and $\mathrm{CO}$ mixing ratios also change along the transect of the filament (Fig. 6a). Increased $\mathrm{O}_{3}$ (blueish dots, Fig. 6a, d) is expected to shift $\mathrm{NO} / \mathrm{NO}_{2}$ photochemically towards $\mathrm{NO}_{2}$, and $\mathrm{NO}_{2}$ is part of $\mathrm{NO}_{y}$. Thus increased $\mathrm{O}_{3}$ should decrease the $\mathrm{NO} / \mathrm{NO}_{y}$ ratio by lowering NO. The opposite was observed: increased $\mathrm{O}_{3}$ corresponds to increased $\mathrm{NO}$ (Fig. 6d), while corresponding $\mathrm{NO}_{y}$ mixing ratios are almost constant (Fig. 6b). The positive, linear correlation of $\mathrm{NO}$ vs. $\mathrm{O}_{3}$ measurements (Fig. 6d) might in itself be attributed to enhanced $\mathrm{O}_{3}$ production due to increased NO. Such an interpretation would require a positive correlation of $\mathrm{NO}$ vs. $\mathrm{NO}_{y}$ for the entire range of NO mixing ratios. However, positive correlations between $\mathrm{NO}$ and $\mathrm{NO}_{y}$ were only observed for subsets of the data (grey lines in Fig. 6b). To sum up, we interpret the distribution of measurements in $\mathrm{NO}$ vs. $\mathrm{NO}_{y}$ space (Fig. 6b) as the overlay of small variations (noise, scatter) of nitrogen oxide mixing ratios on top of a decreasing $\mathrm{NO} / \mathrm{NO}_{y}$ ratio from outer streamlines towards more inside the ASMA. The latter variation seems to be mainly due to the mixing of reservoirs with different $\mathrm{NO}$ mixing ratios, namely a $\mathrm{NO} \downarrow \downarrow \mathrm{O}_{3}$ reservoir at inner streamlines with $\mathrm{NO} \uparrow \mathrm{O}_{3}$ at outer streamlines. This is consistent with backward trajectories, which also indicate two different reservoirs (Fig. 4a, b, c, d). Lightning is the most likely source of increased NO in older UT ASMA air (see accompanying paper for details), compared to NO-poor, freshly uplifted air.

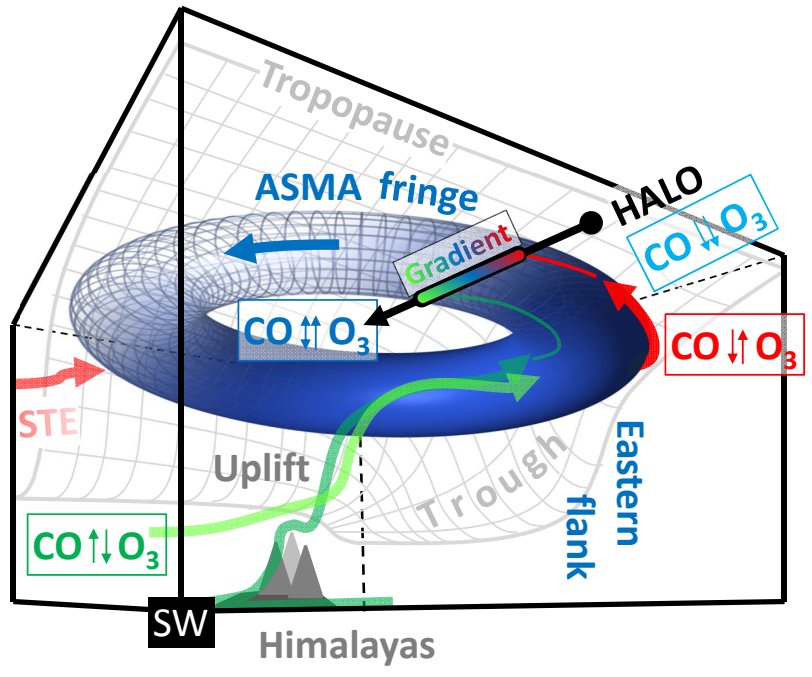

Figure 7. Schematic of the synoptic situation and $\mathrm{CO}-\mathrm{O}_{3}$ trace gas signatures that contributed to the HALO in situ measurements transecting the southern ASMA fringe during the ESMVal campaign (POI3). The foreshortened cuboid is seen from the SW corner. It approximately covers $15-40^{\circ} \mathrm{N}, 40-120^{\circ} \mathrm{E}$, and surface to $100 \mathrm{hPa}$, with features not drawn to scale. Recent contributions of stratospheric intrusions (STE) were not detected in the measurements, but might have contributed to the fringe's trace gas signatures earlier. See text for details.

\subsection{Synthesis for POI3 and related UT measurements}

A decreased $\mathrm{CO} \&$ decreased $\mathrm{O}_{3}$ reservoir $\left(\mathrm{CO} \downarrow \downarrow \mathrm{O}_{3}\right.$, indicated by crosses in Fig. 6) contributed to the outer ASMA streamlines, diluting increased $\mathrm{O}_{3}$ signatures there. According to the backward trajectories, $\mathrm{CO} \downarrow \downarrow \mathrm{O}_{3}$ originates from mid-tropospheric air, transported in cyclonic motion below the ASMA, then rapidly uplifted over Myanmar. A medium $\mathrm{CO}$-increased $\mathrm{O}_{3}$ reservoir $\left(\mathrm{CO} \uparrow \uparrow \mathrm{O}_{3}\right)$ contributed to the inner edge of the filament, which is mainly UT air originating from the interior of the ASMA. Note that both reservoirs with increased $\mathrm{O}_{3}\left(\mathrm{CO} \uparrow \uparrow \mathrm{O}_{3}\right.$ and $\left.\mathrm{CO} \downarrow \uparrow \mathrm{O}_{3}\right)$ are not directly connected across parallel trajectories, since $\mathrm{CO} \uparrow \uparrow \mathrm{O}_{3}$ mixes towards the opposite end $\left(\mathrm{CO} \uparrow \downarrow \mathrm{O}_{3}\right)$ of the central mixing line. The gradient between the inner and the outer edge might have been flattened by mixing during transport from the eastern ASMA flank to the measurement location, thereby just shortening the mixing line.

Figure 7 shows a schematic for POI 3 and summarises the main aspects discussed above. The fringe is essentially a transport barrier, separating the ASMA interior from the outside UT. Nevertheless, it interacts with the interior at its inner edge, and with the surroundings at its outer edge, resulting in trace gas gradients perpendicular to the streamlines of the fringe. The outer edge scrapes along the declining tropopause in the north and may entrain the TL when veering into the free troposphere at the eastern flank. Stratospheric intrusions from the tropopause folding hotspot over 
the eastern Mediterranean (Akritidis et al., 2016) may potentially also contribute to the chemical composition of the fringe, but were not detected in the ESMVal measurements. Air uplifted from the lower and middle troposphere dominates the inner edge of the fringe. The trace gas signatures encountered by HALO before entering the fringe, and after leaving it towards the ASMA interior are again different, i.e. not the end members of the gradient in the fringe. Thus the fringe signatures must have been generated somewhere else, most likely at the eastern flank.

The corresponding detailed tracer-tracer relations for POI5 and POI6 are shown in the Supplement (Figs. S6, S7), but we do not discuss them in detail. They belong to different sections of a filament of UT ASMA air that was more or less entrained by deep convection at the eastern ASMA flank. The mixing lines of POI6 may even be dominated by different amounts of in-mixing from the tropopause region, rather than by air from the lower troposphere. A detailed quantification of the different processes' contribution to individual measurements would, however, require more sophisticated analyses along back-trajectories.

\section{Origins of observed ASMA trace gas signatures}

\subsection{Entraining the TL}

During the POIs HALO was flying well below the tropopause. All observed tracer mixing ratios are clearly tropospheric, and all back-trajectory end points are in the troposphere. There is no indication of back-trajectories crossing the TP, which steeply slopes over the Tibetan Plateau and is hard to define accurately there (Ren et al., 2014). Here it is only important to note that backward trajectories do not indicate any contribution from high above the tropopause region. This TL is subject to mixing, small-scale stirring, convection (mainly tropical TL) and isentropic transport (mainly extratropical TL). All these processes involve cross-tropopause trajectories, but our Lagrangian calculations would only capture large-scale transport. The Eulerian EMAC simulations also reproduce large-scale transport, but additionally capture small-scale stirring/mixing as diffusive processes and convective transport. The latter is controlled by the convection parameterisation.

There is a conspicuous filament of increased $\mathrm{HCl} \&$ decreased $\mathrm{CO}$ signatures extruding from the tropopause trough at the eastern ASMA flank (black arrows in Fig. 2b, d). This indicates entrainment of TL air, which has a more stratospheric signature compared to the surrounding upper tropospheric air. The filament is hardly recognisable in the snapshot of $\mathrm{O}_{3}$ from our simulation (Fig. 2a), because there are no big differences between $\mathrm{O}_{3}$ mixing ratios in the fringe and those in the interior.

Figure 4 shows that air in the fringe travels at almost constant altitude. It is scraping along the tropopause in the north, entraining the TL mixing zone. A filament with increased mixing ratios of $\mathrm{HCl}$ and $\mathrm{O}_{3}$ is dragged into the troposphere (away from the TP) at the eastern ASMA flank, but at the same time the decreased $\mathrm{NO}_{y}$ zone at the tropopause is not disrupted (Fig. 2c). There is entrainment from the TL, but not from far above the TP. This process obviously contributes to increased $\mathrm{HCl} \& \mathrm{O}_{3}$ mixing ratios in the ASMA fringe.

In situ measurements across the TP at eastern ASMA flank would be desirable, but we are not aware of any such measurements from that region. In fact, POI3 of the HALO ESMVal campaign seems to provide the closest snapshot so far of trace gases from that region of interest. The trace gas signatures acquired by the outer ASMA streamlines at the eastern ASMA flank were carried almost unperturbed along the southern flank to the measurement location. The preservation of trace gas gradients (Figs. 1, 6) indicates little mixing. In the following, we therefore take a closer look at the eastern flank as simulated by EMAC.

\subsection{Air masses of POI3 at the eastern ASMA flank}

The signature of the air mass observed during POI3 was formed when it passed the eastern ASMA flank 3 days before the HALO flight (see $72 \mathrm{~h}$ back-trajectories in the Supplement Fig. S5). The back-trajectories (Fig. 4b) also show that the UT part of air mass encountered during POI3 had been travelling at an almost constant altitude for the time of circling the entire ASMA. Only when the flow is forced southwards at the eastern ASMA flank, trajectories briefly follow the steeply ascending TP (Fig. 4b: deep blue shadings in the NE part of the ASMA). Ascending trajectories in that region could also be the result of convective activity that is not explicitly resolved in the reanalysis data, but still represented as regional uplift). The trajectories, however, descend to their original altitudes after separation from the TP trough at the eastern ASMA flank, implying the existence of a flow component perpendicular to the TP when veering away. The flow field is also strongly divergent in the horizontal (see forward and backward trajectories from the eastern ASMA flank in Appendix A, Fig. A2). As a result, air from the TL is dragged southwards into the UT.

Figure 8 zooms into the simulated distribution of different trace gases on 15 September 2012, 08:00 UTC, at the eastern ASMA flank. A TP trough develops at the eastern flank at that time. TL air is entrained there into the ASMA fringe, as indicated by a filament with characteristic trace gas signatures: increased $\mathrm{HCl}$ (white arrow in Fig. 8a), decreased $\mathrm{CO}$ (Fig. 8d) and increased $\mathrm{O}_{3}$ (Fig. 8g) are all relative to the surrounding UT air. Rising air from the Tibetan conduit arrives at the pictured altitude at the inner streamlines of the filament, contributing air enriched in $\mathrm{CO}$, but depleted in $\mathrm{HCl}$ and $\mathrm{O}_{3}$. This lower-tropospheric air mass determines the inner streamlines of the ASMA fringe. Meridional curtains (middle column of Fig. 8) contain the centre of the air mass that was encountered by HALO during POI3. Going back 


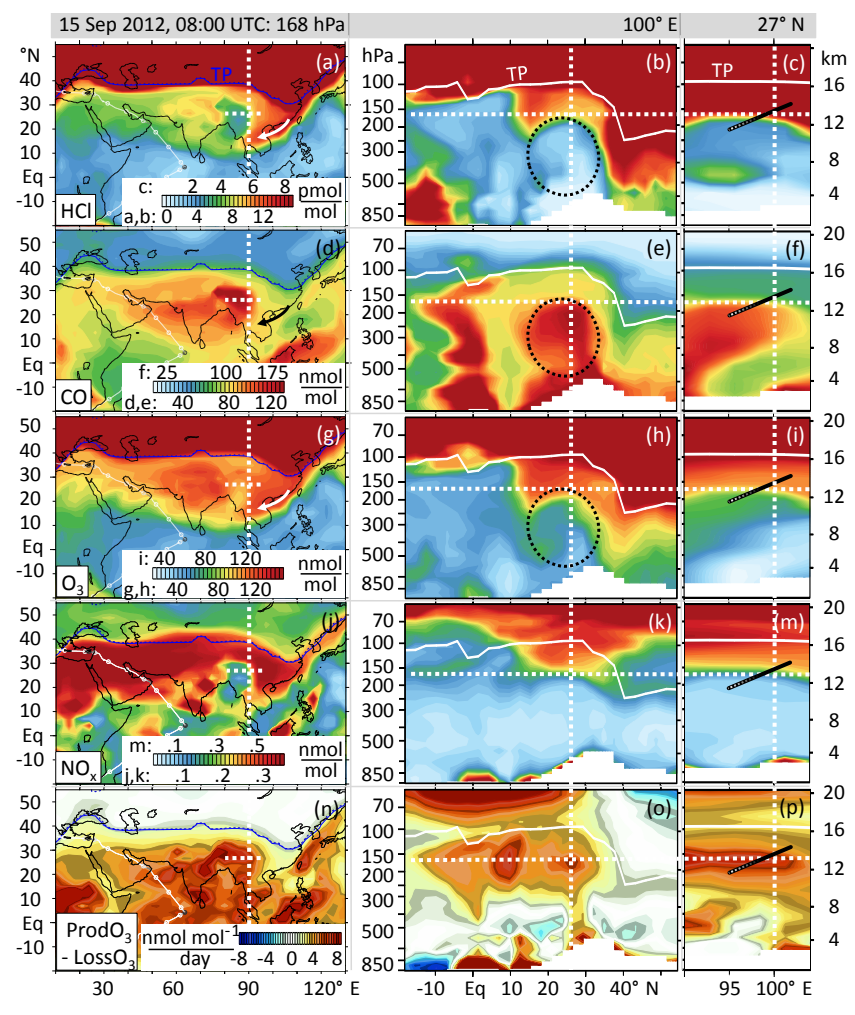

Figure 8. Mixing ratios of $\mathrm{HCl}, \mathrm{CO}, \mathrm{O}_{3}, \mathrm{NO}_{x}$, and net photochemical $\mathrm{O}_{3}$ production as simulated by EMAC for 08:00 UTC on 15 September 2012. Black bars in the right column indicate the air mass to be encountered by HALO 3 days later. That air mass was passing the eastern flank of the anticyclone at the pictured time. Its eastern part was entrained by uplifted air there, creating a trace gas gradient in the fringe. Zonal and meridional curtains are shown on the right, and positions of the respective two panels are marked by dashed lines in each panel. Arrows and circles indicate features discussed in the text.

$72 \mathrm{~h}$ from POI3, the HALO flight path corresponds approximately to an inclined zonal transect at $27^{\circ} \mathrm{N}$ (see Supplement Fig. S5). Those simulated zonal transects (black bars in right column of Fig. 8) nicely reflect the trace gas gradients observed during POI3. We note that $\mathrm{O}_{3}$ is positively correlated with $\mathrm{HCl}$, and both are anti-correlated with $\mathrm{CO}$ at the eastern ASMA flank. This is consistent with a common origin of increased- $\mathrm{O}_{3} \&$ increased-HCl signatures, supporting the hypothesis of TL contributions to the UT ASMA air. The plume of uplifted air that dominates the inner streamlines encountered during $\mathrm{POI} 3$ is in contrast characterised by increased $\mathrm{CO}$ and decreased $\mathrm{HCl} \& \mathrm{O}_{3}$ (circled in Fig. 8b, e, h).

The trace gas signatures of outer and inner streamlines of POI3 are shaped simultaneously at the eastern ASMA flank. However, the outer parts of the ASMA fringe that mainly entrained the TL at the eastern flank were only marginally part of the filament which was transected by HALO. The air mass to be observed (centred at crosshairs in Fig. 8) was too far west of the eastern ASMA edge (arrows in Fig. 8a, g, j). We cannot quantify, from our analysis, how much TL entrainment contributed to the decreased-CO \& increased- $\mathrm{O}_{3}$ signature $\left(\mathrm{CO} \downarrow \uparrow \mathrm{O}_{3}\right)$ measured at the beginning of POI3. The small amount of scatter on the mixing line between $\mathrm{CO} \downarrow \uparrow \mathrm{O}_{3}$ and $\mathrm{CO} \uparrow \downarrow \mathrm{O}_{3}$ (Fig. 6a) indicates that only two reservoirs contributed, and that $\mathrm{CO} \downarrow \uparrow \mathrm{O}_{3}$ had been the signature of the fringe before arriving at the eastern flank already. In that case, the corresponding streamlines would not have acquired a modified signature at the eastern ASMA edge, but only have veered away from the TP there. Then the gradient between $\mathrm{CO} \downarrow \uparrow \mathrm{O}_{3}$ and $\mathrm{CO} \uparrow \downarrow \mathrm{O}_{3}$ during POI3 is a consequence just of adding $\mathrm{CO} \uparrow \downarrow \mathrm{O}_{3}$ to the inner edge of the filament. However, even if the TL air entrained by the more outer streamlines around 15 September (Fig. 8) did not contribute to the HALO measurements, it still becomes part of the outer streamlines of the ASMA circulation. Increased $\mathrm{HCl}$ mixing ratios in the measurements indicate that earlier such events indeed have contributed to the trace gas signatures of the UT air that was already circling in the fringe before arriving at the eastern ASMA edge.

\subsection{Photochemical $\mathrm{O}_{3}$ production}

How did photochemical $\mathrm{O}_{3}$ production affect the $\mathrm{O}_{3}$ gradient between inner and outer edge of the POI3-filament? According to EMAC, photochemical $\mathrm{O}_{3}$ production is expected to be enhanced towards the ASMA interior (Fig. 8n, o, p), where measurements of $\mathrm{O}_{3}$ were lower than at streamlines during POI3. Increased $\mathrm{O}_{3}$ mixing ratios were measured at the outer edge of the filament, where aged UT air dominates. Thus the measured mixing line cannot be explained by photochemical $\mathrm{O}_{3}$ production after the air mass had passed the eastern ASMA flank. On the contrary, integral photochemical $\mathrm{O}_{3}$ production along the transport path acts to level the gradient.

The distributions of both main $\mathrm{O}_{3}$ precursors, $\mathrm{NO}_{x}$ and $\mathrm{CO}$, print through as locally enhanced net $\mathrm{O}_{3}$ production in Fig. 8n. $\mathrm{Net}_{3}$ production seems to depend more on $\mathrm{CO}$ (and related precursors) than on $\mathrm{NO}_{x}$. Figure $8 \mathrm{f}, \mathrm{m}$, p again show that $\mathrm{O}_{3}$ production is maximal in the altitude range, where increased $\mathrm{CO}$ meets increased $\mathrm{NO}_{x}$ mixing ratios. $\mathrm{NO}_{x}$ is limited below, $\mathrm{CO}$ and volatile organic compounds above.

Could the high $\mathrm{O}_{3}$ signature of the aged UT air $\left(\mathrm{CO} \downarrow \uparrow \mathrm{O}_{3}\right)$ be due to in situ photochemical $\mathrm{O}_{3}$ production alone? Opposite gradients of net ozone production and ozone mixing ratios could also be explained by aged air (decreased $\mathrm{O}_{3}$ production, increased $\mathrm{O}_{3}$ ) circling in the fringe, and entrainment of young air (increased $\mathrm{O}_{3}$ production, decreased $\mathrm{O}_{3}$ ) at the inner edge of the filament. No TP entrainment would be needed in such a scenario of ageing uplifted air to explain increased $\mathrm{O}_{3}$ mixing ratios. It is, however, inconsistent with the $\mathrm{HCl}$ and $\mathrm{CO}$ gradients in the transected filament, which have been observed (Fig. 6) and simulated (Figs. 2, 6). Thus entrainment from the TL - either on 15 September at the eastern ASMA flank or before - did contribute to the signature 
of the fringe filament encountered by HALO. Photochemical ageing certainly also has contributed to raise $\mathrm{O}_{3}$, at least for 9 days of circling in the fringe.

\section{Is $\mathrm{O}_{3}$ enhanced or decreased in the ASMA?}

Based on the general picture provided by previous studies, we had expected to find decreased $\mathrm{O}_{3}$ in the ASMA compared to the surrounding UT, but found increased mixing ratios instead. Thus either our presumption of generally decreased $\mathrm{O}_{3}$ in the ASMA is wrong, or HALO encountered an unusual situation. In the following we revisit studies that advocated the picture of decreased $\mathrm{O}_{3}$ in the ASMA (Randel and Park, 2006; Park et al., 2007, 2008; Kunze et al., 2010, 2016), while the frequency of occurrence of the processes needed to explain the in situ data is further discussed in the accompanying paper.

Randel and Park (2006) and Kunze et al. (2010) base their analyses of $\mathrm{O}_{3}$ on isentropic vertical coordinates, mainly the $360 \mathrm{~K}$ potential temperature level. Kunze et al. (2016) find a quite persistent pattern of decreased $\mathrm{O}_{3}$ concentrations during strong monsoon seasons on the isentropic levels 360 to $380 \mathrm{~K}$. Isentropes tend to form a trough in the ASMA, when viewed in pressure coordinates, due to diabatic heating over the Tibetan Plateau (Ren et al., 2014). Thus it is more likely to find lower-tropospheric trace gas signatures in the ASMA interior on potential temperature surfaces than on pressure levels. EMAC simulated $\mathrm{O}_{3}$ in the ASMA is indeed decreased on isentropic levels, but at the same time increased on various UT pressure levels in the same altitude range (see Supplement S4).

However, Park et al. (2007) report an $\mathrm{O}_{3}$ minimum in the ASMA at the pressure level of $100 \mathrm{hPa}$, for July and August 2005. That is based on MLS retrievals, which were recently found to have some low $\mathrm{O}_{3}$ bias at around $100 \mathrm{hPa}$ (Yan et al., 2016). Our simulation, nevertheless, reproduces an $\mathrm{O}_{3}$ minimum at $100 \mathrm{hPa}$ in the ASMA for July and August in 2005 and 2012 (see Supplement Figs. S2 and S3). No $\mathrm{O}_{3}$ minimum is simulated for September $(2005,2012)$, and neither for 150 nor $200 \mathrm{hPa}$ in any month during the monsoon season.

Park et al. (2008) report an $\mathrm{O}_{3}$ minimum inside the ASMA based on retrievals from another space borne sensor (ACEFTS). They flag profiles as being "inside" the ASMA, if CO $\geq 60 \mathrm{nmol} \mathrm{mol}^{-1}$ at $16.5 \mathrm{~km}$. Co-located retrievals then show decreased mixing ratios of $\mathrm{O}_{3}$ and stratospheric tracers (e.g. $\mathrm{HCl}$ ) for the inside bin in contrast to the outside bin. This approach rather identifies an anti-correlation of $\mathrm{CO}$ and $\mathrm{O}_{3}$ in the UT than generally decreased $\mathrm{O}_{3}$ inside the ASMA. Such an anti-correlation is also indicated in the EMAC simulated snapshot shown in Fig. 2.

Summarising this section, our simulation is able to reproduce decreased $\mathrm{O}_{3}$ in the ASMA for those special circumstances it has been reported by other studies. At the same time, we found no indication in our simulation to expect decreased $\mathrm{O}_{3}$ in the ASMA at about $150 \mathrm{hPa}$ in September. The $\mathrm{O}_{3}$ measurements taken during HALO ESMVal in the fringe (POI3) and more inside the ASMA (POI5, POI6) are consistent with that simulated September mean $\mathrm{O}_{3}$ distribution, although only two analysed seasons strictly may provide not more than a strong indication of climatological trace gas signatures in the ASMA. Rather than attributing the trace gas signatures measured by HALO to an unusual situation, we assume that presumptions dominated by midsummer data might not be valid towards the end of the monsoon season. Possible reasons for the differences between July/August versus September might include the longer time available for photochemical build-up of $\mathrm{O}_{3}$ in the ASMA, decreasing resupply of $\mathrm{O}_{3}$-poor air towards the end of the monsoon season, more in-mixing of $\mathrm{O}_{3}$-rich $\mathrm{TL}$ air into the decaying ASMA (dynamical instabilities), and changes to the altitudes of maximum $\mathrm{O}_{3}$ production.

\section{Summary}

Our study contributes to the so far sparse ASMA in situ measurements, allowing us to address some of the aspects of this important UT phenomenon that were recently identified as poorly understood (Randel et al., 2016): dynamical and chemical coupling with convection, composition/reactive chemistry in the monsoon region, and mixing of higher latitude lower-stratospheric air into the tropical TL by the ASMA.

Data from the HALO ESMVal campaign that were gathered during a flight from Male (Maldives) to Larnaca (Cyprus) on 18 September 2012 are presented and analysed. That region is particularly unexplored by in situ measurements. HYSPLIT backward trajectories show that HALO was in an UT filament most of the time, which had been part of the UT ASMA circulation for at least 10 days, thereby circulating around the anticyclone. Uplifted air was entrained into the UT filament at the eastern ASMA flank, which was then transported by almost unperturbed, parallel streamlines in the southern ASMA fringe (Fig. 4). Back-trajectories indicate that HALO crossed the filament three times (Fig. 5) in the zone where an originally larger ASMA was just splitting into an Iranian and a Tibetan part (Figs. 3, A2). At least a part of the filament from the eastern ASMA flank is diverted into the new Iranian anticyclone. Based on the in situ measurement data, the first transect of the fringe filament provides the hitherto most direct view of the upstream eastern ASMA flank, where several processes act that have the potential to strongly modify UT trace gas mixing ratios.

A global simulation with the EMAC model is in reasonable agreement with observed trace gas mixing ratios along the HALO flight track. The specified dynamics set-up (nudging) certainly enforces a better agreement between simulation and observations, compared to what could be expected 
from a free-running simulation. The synoptic scale of the ASMA acts to alleviate discrepancies that are related to the limited spatial and temporal resolution of the simulation, but a perfect agreement cannot be expected. Overall we find that this simulation is well suited to be used for further interpretation of the measurements. An ASMA splitting event indicated by back-trajectories is also reproduced by the EMAC simulation (Fig. 3) and further analysed in the accompanying paper.

Based on the general picture provided by previous studies, depleted $\mathrm{O}_{3}$ mixing ratios were expected in the ASMA compared to the surrounding UT. However, enhanced $\mathrm{O}_{3}$ was found in the ASMA filament encountered by HALO. In order to identify the processes that generated this $\mathrm{O}_{3}$ signature, additional tracers are considered for further analyses: $\mathrm{CO}$ as marker for lower-tropospheric air, $\mathrm{HCl}$ for stratospheric or TL origins, $\mathrm{NO}$ and $\mathrm{NO}_{y}$ as important players in $\mathrm{O}_{3}$ photochemistry. All above-mentioned tracers were measured in situ, and their mixing ratios steeply increase across the boundary of the ASMA filament compared to the adjoining clean air in the south.

Tracer-tracer relations of the in situ data are consistent with a mix of UT and lower-tropospheric air in the ASMA fringe. Two effects likely have contributed to the observed signatures of increased $\mathrm{O}_{3}$ : photochemical $\mathrm{O}_{3}$ production and entrainment of stratospheric or TL air. The EMAC simulation indicates that net photochemical $\mathrm{O}_{3}$ production is maximal, where uplifted air with $\mathrm{O}_{3}$ precursors originating in boundary layer pollution (e.g. CO) mixes with UT air that is enriched in (lightning) NO, another precursor. Besides increased $\mathrm{O}_{3}$, mixing ratios of the stratospheric tracer $\mathrm{HCl}$ are also relatively enhanced in air that had been part of the UT ASMA for longer. This trace gas signature cannot be explained by photochemical ageing of uplifted, lowertropospheric air alone. The EMAC simulation indeed shows that a TL filament with more stratospheric trace gas signatures than the surrounding UT air is entrained into the ASMA fringe at a tropopause trough at the eastern flank of the anticyclone (Figs. 2 and 7). It is dragged away from the TP and deeper into the troposphere, circling around the ASMA interior. That particular event hardly contributed to the simulated data on the flight track, but timing and location are such that - given the uncertainties of the simulation - in reality the corresponding event might still have contributed to the observed air composition. If this is not the case, then earlier such entrainment events contributed to the ASMA trace gas signatures - in both the simulation and the measurements.

Dynamical instabilities, like the ASMA splitting event encountered by HALO, provide a means to overcome the radial transport barriers presented by closed streamlines and to effectively stir the previously entrained TL air into the ASMA interior.
Our current study focuses on the detailed analysis of a single transect of in situ data through one part of the ASMA, close to the end of the monsoon season. The relevance of the involved processes - entrainment of TL air into the ASMA fringe, photochemistry and stirring - for the trace gas distributions in the ASMA is further explored in the accompanying paper. We nevertheless found that the EMAC simulation is able to reproduce decreased $\mathrm{O}_{3}$ mixing ratios in the ASMA at $100 \mathrm{hPa}$ for July and August as reported by previous studies, but it also reproduces increased $\mathrm{O}_{3}$ as observed during the HALO ESMVal campaign. Decreased $\mathrm{O}_{3}$ was found in the simulation neither for lower altitudes nor September monthly mean values, and the apparent contradiction to previous studies vanishes in this more differentiated view. The incidence of $\mathrm{O}_{3}$-rich air in the ASMA - as seen in the simulated monthly mean data - indicates that the ESMVal in situ measurements could even represent a common composition of the ASMA at about $150 \mathrm{hPa}$.

Data availability. The simulation results analysed here are archived at the German Climate Computing Center (DKRZ) and are available on request. It is planned to move them to the Climate and Environmental Retrieval and Archive (CERA) database at the German Climate Computing Centre (DKRZ; http://cera-www.dkrz.de/ WDCC/ui/Index.jsp). The corresponding digital object identifiers (doi) will be published on the MESSy consortium web page (http: //www.messy-interface.org). The observational data of the HALO ESMVal flight used here are available from the HALO database: https://halo-db.pa.op.dlr.de/dataset/830. Registration is needed to access the data (https://halo-db.pa.op.dlr.de/account/register). 


\section{Appendix A: Other flight segments}

\section{A1 POI1}

The first part of the flight consists of the take-off and ascent from Male. It is not directly related to the ASMA and not further discussed here.

\section{A2 POI2}

HALO was flying in the UT in a north-westerly direction towards the Arabian Peninsula. POI2 ends south-east of the Oman coast with the sudden increase of measured $\mathrm{O}_{3}$ and other trace gas mixing ratios (Fig. 1). The corresponding back-trajectories (Fig. A1) indicate that air masses came from the Far East Pacific coast, from the boundary layer of south-east Asia, and from the ASMA. Mixing ratios of $\mathrm{O}_{3}, \mathrm{CO}, \mathrm{HCl}$ and nitrogen oxides are significantly decreased compared to the following flight segment, indicating that POI2 is dominated by clean air. We do not consider this adjoining air part of the ASMA, although it may get entrained occasionally. The back-trajectories for this flight segment depend critically on the HYSPLIT start time, indicating very dynamic wind fields and possibly inaccurate trajectories. This might also be the reason that EMAC simulation results for some tracers showed different gradients than observed. We therefore decided not to analyse this flight segment in greater detail here, although it might be interesting for characterising the southern boundary region of the ASMA.

\section{A3 POI3}

This flight segment is discussed in Sect. 3. Here (Fig. A2) only backward and forward trajectories starting at the eastern ASMA flank are shown to illustrate the strongly divergent flows that may have affected the transition from POI2 to POI3.

\section{A4 POI4}

Back-trajectories from the following dive over Oman are shown in Fig. A3. The dive was intended to explore the vertical structure of the ASMA and its lower boundary. However, almost immediately below the flight altitude of POI3 the back-trajectories no longer clearly indicate direct transport of air from the eastern ASMA flank. The flight segments at the beginning and at the end of the dive, each covering the altitude range from about 180 to $400 \mathrm{hPa}$, show a more or less curled-in structure similar to POI5 (Fig. 5) near the HALO track. This indicates complex stirring. The anticyclonic motion in the upper parts of POI4 is much slower than in the ASMA above, which was sampled during neighbouring POI3/5: air masses of POI5 travelled almost twice as far as those of POI4 within 11 days (Fig. A4 vs. Fig. A3). Just for reproducibility, the lower boundary of the ASMA was de- fined as the region where no back-trajectory was circling the entire ASMA and reaching the southern flank within $280 \mathrm{~h}$ anymore. There is almost no transition between fast and slow air masses, indicating a sharp lower boundary of the ASMA in terms of wind speeds. However, our pragmatic criterion might not work in general and should not be applied to other cases without further analysis. The two high-altitude parts of POI4 might, in principle, be useful for characterising the lower boundary of the ASMA, but that would require a dedicated analysis and is not the focus of our study. At lower altitudes ( $\sim 400$ to $650 \mathrm{hPa}$ ), the origin of air encountered during the dive shifts towards the Mediterranean and Europe, which is also not further analysed here.

\section{A5 POI5 and POI6 (POI5/6)}

The next two flight segments lead from the Persian Gulf to the eastern Mediterranean (5 and 6 in Fig. 2a). Like POI3, they are characterised by almost parallel streamlines from the eastern ASMA flank, along the southern fringe, to the measurement location. The filament of UT air was curled in horizontally in such a way that the (former) ASMA fringe was transected during POI5 (Fig. A4) outside-in, then insideout during POI6 (Fig. A5). This complex structure of the streamlines is a consequence of an ASMA splitting or eddy shedding event that occurred during the ESMVal campaign (discussed in more detail in the accompanying study). The original ASMA encompassed South Asia and the Arabian Peninsula (Fig. 4a, b, c). HALO crossed the zone where the original ASMA separated into two smaller anticyclones, one centred over the Iranian Plateau and one centred over Tibet. The air masses contributing to POI3/5/6 all passed the eastern ASMA edge over South Asia, but at least POI5 is bound to become part of the Iranian anticyclone after the splitting. The transition from POI5 to POI6 was chosen according to the initial direction of back-trajectories changing from right to left of the HALO track. We regard the transition from POI5 to POI6 as a pragmatic estimate only, as it is essentially the same air mass. According to a zoomed-in image (not shown) the back-trajectories were also curled in vertically at the transition from POI5 to POI6 to some degree, indicating complex small-scale dynamics. The back-trajectories for POI5/6 show that the anticyclonic motion encompassed northern Africa earlier in September 2012, which also applies to POI2. However, unlike for POI2 it did not extend far into East Asia. UT air contributing to POI3/5/6 passed the eastern ASMA flank mainly over South Asia. We also note that the outer ASMA edge was only crossed during the beginning of POI3, and we pragmatically chose a steep gradient of $\mathrm{O}_{3}$ mixing ratios to distinguish the ASMA from outside air. The flight path could have transected the former outer ASMA edge two more times, due to the curled-in structure of the filament (Fig. 5). However, HALO dived below the ASMA at the beginning of POI5 and at the end of POI6. Measurements at the original flight level might have provided more information about the 


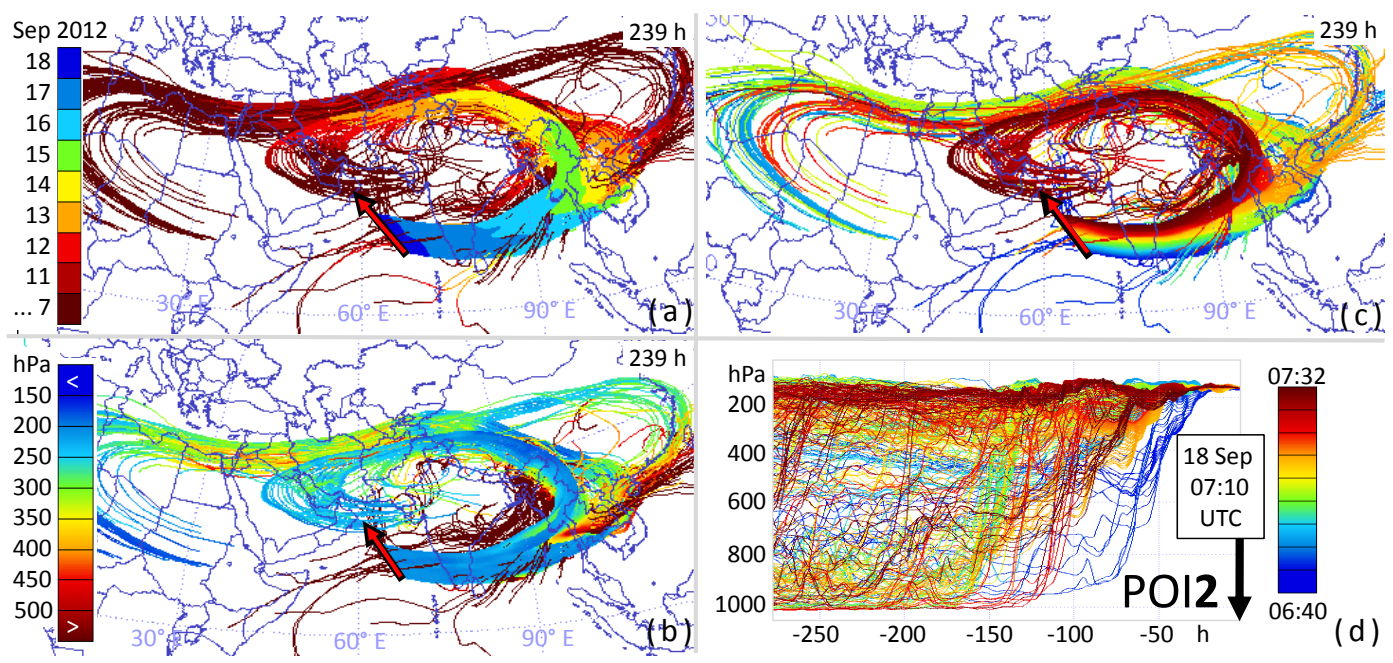

Figure A1. As Fig. 3, but for POI2. This flight segment covers the time after take-off and ascent until increased $\mathrm{O}_{3}$ mixing ratios are encountered.

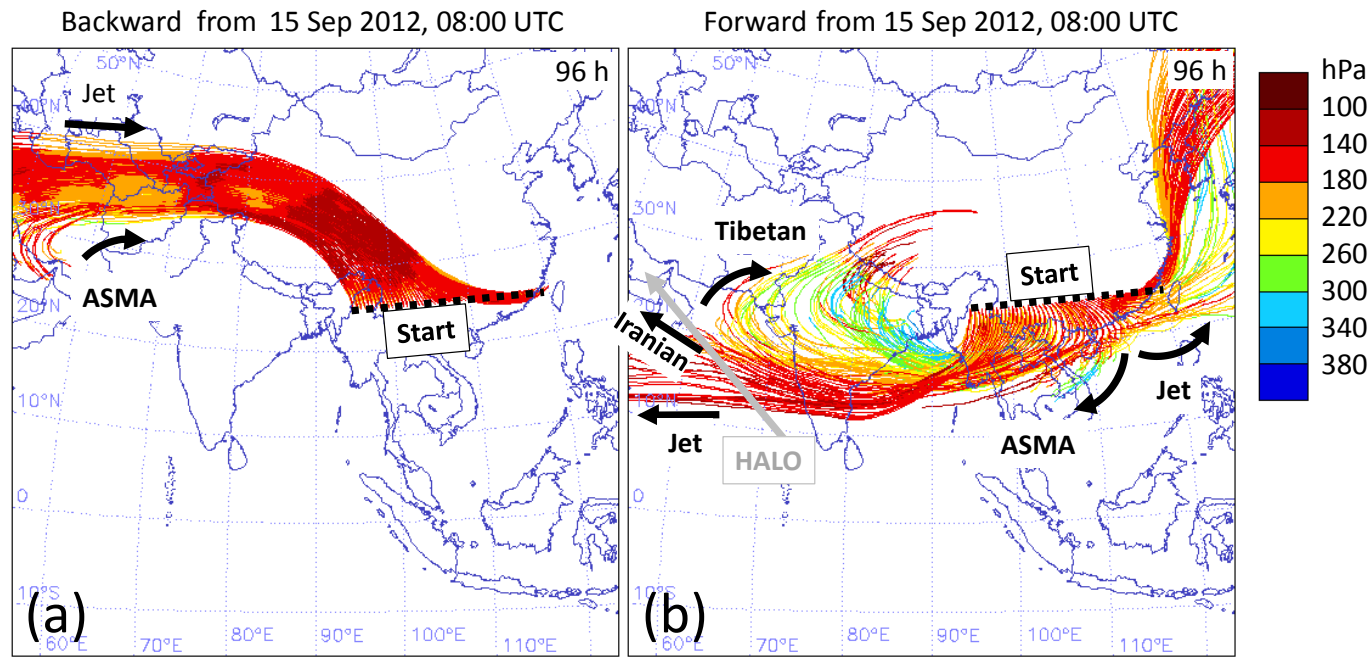

Figure A2. Four-day backward (a) and four-day forward (b) trajectories, starting between 12 and $14 \mathrm{~km}$ altitude. The trajectories start from a plane intersecting the eastern ASMA edge when the air mass measured by HALO during POI3 was there. The wind field is strongly divergent at the eastern ASMA flank, where the subtropical jet separates from the anticyclone. During the time covered by the trajectories the anticyclone split into a Tibetan and an Iranian part, just where HALO was passing through.

ASMA boundary, because the separation of ASMA air from outside air had already taken place for those older parts of the filament.

\section{A6 POI7}

The descent into Larnaca (Fig. A6) shows some similarities to the dive over Oman. As in POI4, the anticyclonic motion becomes slower with decreasing altitude and the air encountered above about $400 \mathrm{hPa}$ has a mainly South Asian origin. Back-trajectories starting at the flight track at the northwestern flank of the ASMA below a pressure altitude of about $130 \mathrm{hPa}$ do not encircle the anticyclone within $280 \mathrm{~h}$. In contrast, those starting at higher altitudes do. POI7 is not further discussed here, but might be considered in future studies to characterise the lower ASMA boundary. 


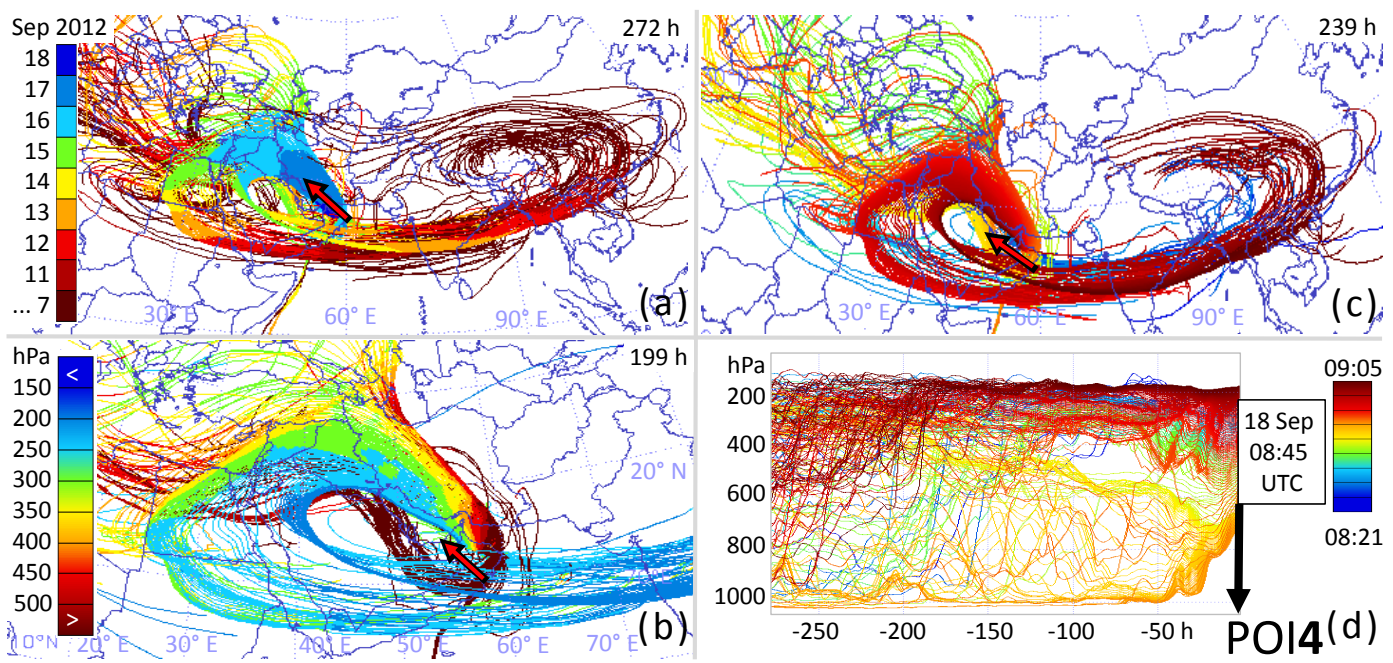

Figure A3. As Fig. 3, but for POI4. This flight segment covers the dive from the UT into the mid-troposphere. The interval for POI4 is chosen such that anticyclonic motion is much slower compared to the ASMA circulation above: air from the highest altitudes of POI4 does not quite circle the ASMA within $300 \mathrm{~h}$, while air from POI3/5 needs about 200 and $280 \mathrm{~h}$ (Figs. 3, A4). The source regions contributing to POI4 primarily depend on the actual flight altitude; i.e. the sequence of air masses encountered during descent is mirrored during the following ascent.

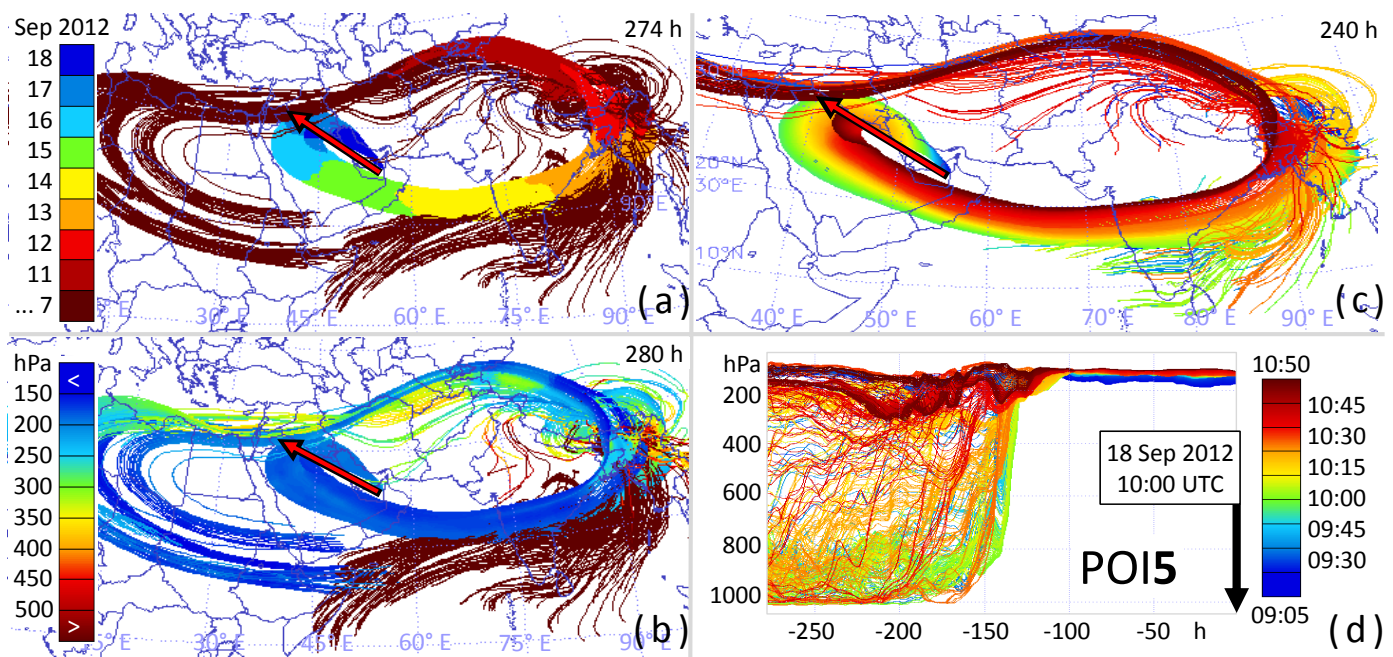

Figure A4. As Fig. 3, but for POI5. This flight segment is dominated by UT ASMA air, entrained by convection. 


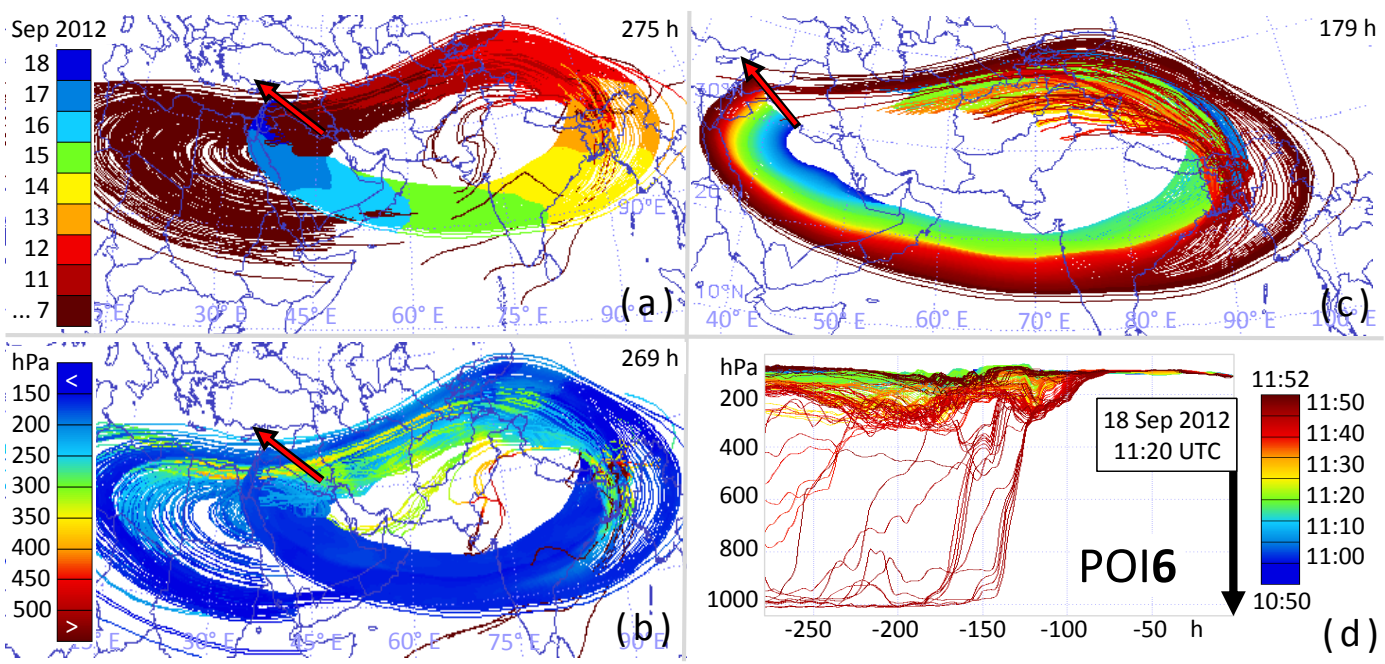

Figure A5. As Fig. 3, but for POI6. This flight segment is dominated by UT ASMA air.

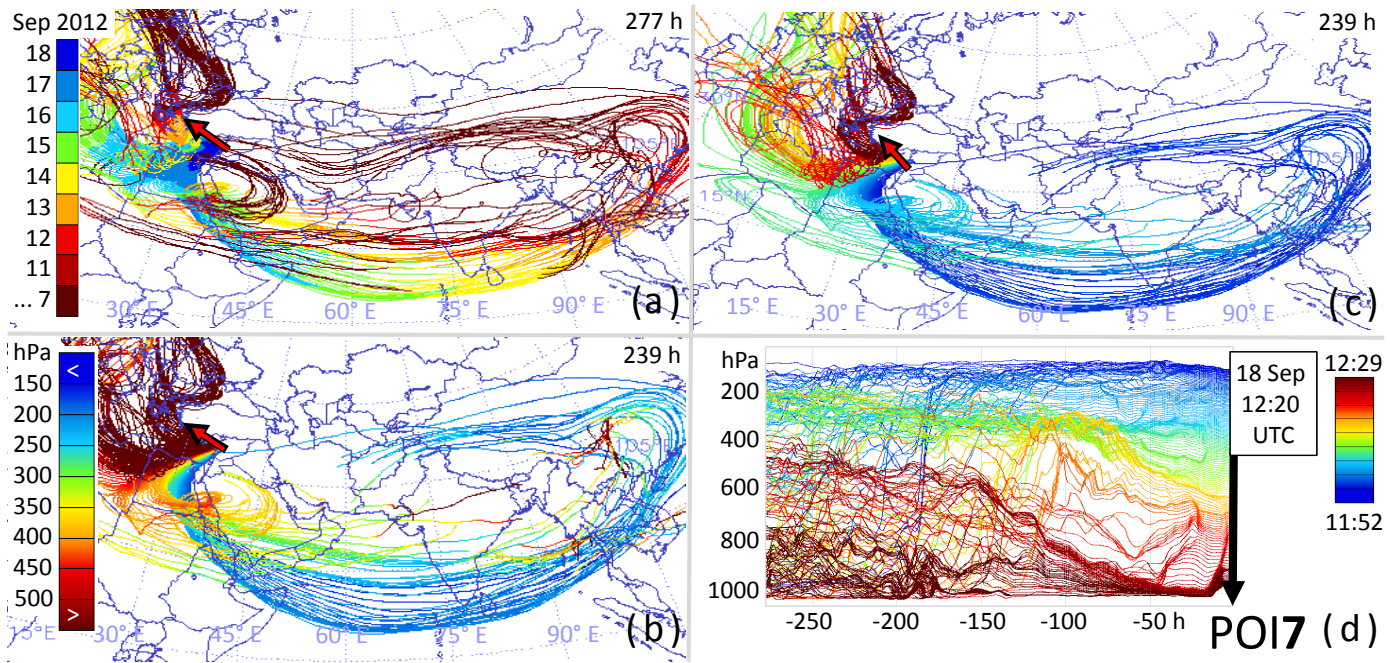

Figure A6. As Fig. 3, but for POI7. This flight segment covers the descent into Larnaca. 


\section{The Supplement related to this article is available online at doi:10.5194/acp-17-6091-2017-supplement.}

Author contributions. K. Gottschaldt analysed the EMAC and in situ data, conducted the Lagrangian calculations, produced the plots and drafted the paper. H. Schlager conceived the study, led the ESMVal HALO campaign, interpreted EMAC and in situ data. R. Baumann wrote and helped with the code that facilitated the HYSPLIT calculations. V. Eyring conceived and led the ESMVal project. H. Bozem and P. Hoor supplied the $\mathrm{CO}$ in situ measurements. P. Jöckel led the ESCiMo project, coordinated the preparation of and conducted the EMAC simulations. T. Jurkat and C. Voigt supplied the $\mathrm{HCl}$ measurements. A. Zahn was responsible for the $\mathrm{O}_{3}$ measurements. H. Ziereis contributed the $\mathrm{NO}_{y}$ measurements. All authors contributed to the text.

Competing interests. The authors declare that they have no conflict of interest.

Acknowledgements. The authors gratefully thank H. Garny and two anonymous referees for valuable comments on the manuscript, B. Brötz, F. Frank, K. Graf, V. Grewe, H. Huntrieser, P. Konopka, R. Müller, M. Nützel, L. Pan, R. Ren, and B. Vogel for helpful discussions.

We thank the German Science Foundation DFG for funding within HALO-SPP 1294 under contracts JU 3059/1-1, SCHL 1857/2-2, SCHL 1857/4-1, VO 1504/2-1 and VO 1504/4-1. The ESMVal aircraft campaign was funded by the DLR-Project ESMVal. KG and HS appreciate support by the EU project StratoClim (grant no. 603557) and BMBF project Spitfire (grant no. 01LG1205B). C. Voigt and T. Jurkat thank financing by the Helmholtz Association under contract no. VH-NG-309 and under contract No. W2/W3-60. In addition we thank the flight department of DLR for their great support during the campaign. S. Müller contributed to the CO measurements and $\mathrm{S}$. Kaufmann supervised the $\mathrm{HCl}$ measurements during the flight.

The EMAC model simulations were performed at the German Climate Computing Centre (DKRZ) through support from the Bundesministerium für Bildung und Forschung (BMBF). DKRZ and its scientific steering committee are gratefully acknowledged for providing the HPC and data archiving resources for the projects 853 (ESCiMo - Earth System Chemistry integrated Modelling) and 854 (ESMVal - Erdsystemmodellevaluierung).

We used the NCAR Command Language (NCL) for data analysis and to create some of the figures of this study. NCL is developed by UCAR/NCAR/CISL/TDD and available online: doi:10.5065/D6WD3XH5.

The article processing charges for this open-access publication were covered by a Research Centre of the Helmholtz Association.

The article processing charges for this open-access

publication were covered by a Research

Centre of the Helmholtz Association.

Edited by: M. von Hobe

Reviewed by: two anonymous referees

\section{References}

Akritidis, D., Pozzer, A., Zanis, P., Tyrlis, E., Škerlak, B., Sprenger, M., and Lelieveld, J.: On the role of tropopause folds in summertime tropospheric ozone over the eastern Mediterranean and the Middle East, Atmos. Chem. Phys., 16, 14025-14039, doi:10.5194/acp-16-14025-2016, 2016.

Baker, A. K., Schuck, T. J., Slemr, F., van Velthoven, P., Zahn, A., and Brenninkmeijer, C. A. M.: Characterization of nonmethane hydrocarbons in Asian summer monsoon outflow observed by the CARIBIC aircraft, Atmos. Chem. Phys., 11, 503518, doi:10.5194/acp-11-503-2011, 2011.

Barret, B., Sauvage, B., Bennouna, Y., and Le Flochmoen, E.: Upper-tropospheric $\mathrm{CO}$ and $\mathrm{O}_{3}$ budget during the Asian summer monsoon, Atmos. Chem. Phys., 16, 9129-9147, doi:10.5194/acp-16-9129-2016, 2016.

Bergman, J. W., Fierli, F., Jensen, E. J., Honomichl, S., and Pan, L. L.: Boundary layer sources for the Asian anticyclone: Regional contributions to a vertical conduit, J. Geophys. Res.-Atmos., 118, 2560-2575, doi:10.1002/jgrd.50142, 2013.

Chen, B., Xu, X. D., Yang, S., and Zhao, T. L.: Climatological perspectives of air transport from atmospheric boundary layer to tropopause layer over Asian monsoon regions during boreal summer inferred from Lagrangian approach, Atmos. Chem. Phys., 12, 5827-5839, doi:10.5194/acp-12-5827-2012, 2012.

Cristofanelli, P., Bracci, A., Sprenger, M., Marinoni, A., Bonafè, U., Calzolari, F., Duchi, R., Laj, P., Pichon, J. M., Roccato, F., Venzac, H., Vuillermoz, E., and Bonasoni, P.: Tropospheric ozone variations at the Nepal Climate ObservatoryPyramid (Himalayas, $5079 \mathrm{~m}$ a.s.1.) and influence of deep stratospheric intrusion events, Atmos. Chem. Phys., 10, 6537-6549, doi:10.5194/acp-10-6537-2010, 2010.

Dee, D. P., Uppala, S. M., Simmons, A. J., Berrisford, P., Poli, P., Kobayashi, S., Andrae, U., Balmaseda, M. A., Balsamo, G., Bauer, P., Bechtold, P., Beljaars, A. C. M., van de Berg, L., Bidlot, J., Bormann, N., Delsol, C., Dragani, R., Fuentes, M., Geer, A. J., Haimberger, L., Healy, S. B., Hersbach, H., Hólm, E. V., Isaksen, L., Kållberg, P., Köhler, M., Matricardi, M., McNally, A. P., Monge-Sanz, B. M., Morcrette, J. J., Park, B. K., Peubey, C., de Rosnay, P., Tavolato, C., Thépaut, J. N., and Vitart, F.: The ERA-Interim reanalysis: configuration and performance of the data assimilation system, Q. J. Roy. Meteor. Soc., 137, 553-597, doi:10.1002/qj.828, 2011.

Draxler, R. R. and Hess, G. D.: An overview of the HYSPLIT_4 modelling system for trajectories, dispersion and deposition, Aust. Met. Mag., 47, 295-308, 1998.

Draxler, R. R. and Rolph, G.: HYSPLIT (HYbrid Single-Particle Lagrangian Integrated Trajectory) model access via NOAA ARL READY website, NOAA Air Resources Laboratory, Silver Spring, http://www.arl.noaa.gov/ready/hysplit4.html, last access: 26 June 2015.

Dunkerton, T. J.: Evidence of meridional motion in the summer lower stratosphere adjacent to monsoon regions, J. Geophys. Res., 100, 16675-16688, doi:10.1029/95JD01263, 1995.

Eyring, V., Lamarque, J.-F., Hess, P., Arfeuille, F., Bowman, K., Chipperfield, M. P., Duncan, B., Fiore, A., Gettelman, A., Giorgetta, M. A., Granier, C., Hegglin, M., Kinnison, D., Kunze, M., Langematz, U., Luo, B., Martin, R., Matthes, K., Newman, P. A., Peter, T., Robock, A., Ryerson, T., Saiz-Lopez, A., Salawitch, R., Schultz, M., Shepherd, T. G., Shindell, D., Stähelin, J., Tegt- 
meier, S., Thomason, L., Tilmes, S., Vernier, J.-P., Waugh, D. W., and Young, P. J.: Overview of IGAC/SPARC Chemistry-Climate Model Initiative (CCMI) Community Simulations in Support of Upcoming Ozone and Climate Assessments, SPARC Newsletter, 40, 48-66, 2013.

Garny, H. and Randel, W. J.: Transport pathways from the Asian monsoon anticyclone to the stratosphere, Atmos. Chem. Phys., 16, 2703-2718, doi:10.5194/acp-16-2703-2016, 2016.

Gettelman, A., Kinnison, D. E., Dunkerton, T. J., and Brasseur, G. P.: Impact of monsoon circulations on the upper troposphere and lower stratosphere, J. Geophys. Res., 109, D22101, doi:10.1029/2004jd004878, 2004.

Gottschaldt, K., Voigt, C., Jöckel, P., Righi, M., Deckert, R., and Dietmüller, S.: Global sensitivity of aviation $\mathrm{NO}_{\mathrm{x}}$ effects to the $\mathrm{HNO}_{3}$-forming channel of the $\mathrm{HO}_{2}+\mathrm{NO}$ reaction, Atmos. Chem. Phys., 13, 3003-3025, doi:10.5194/acp-13-3003-2013, 2013.

Gottschaldt, K., Schlager, H., Baumann, R., Cai, D. S., Eyring, V., Graf, P., Grewe, V., Jöckel, P., Jurkat, T., Voigt, C., Zahn, A., and Ziereis, H.: Interplay of dynamics and composition in the Asian summer monsoon anticyclone, Atmos. Chem. Phys. Discuss., submitted, 2017.

Jöckel, P., Tost, H., Pozzer, A., Brühl, C., Buchholz, J., Ganzeveld, L., Hoor, P., Kerkweg, A., Lawrence, M. G., Sander, R., Steil, B., Stiller, G., Tanarhte, M., Taraborrelli, D., van Aardenne, J., and Lelieveld, J.: The atmospheric chemistry general circulation model ECHAM5/MESSy1: consistent simulation of ozone from the surface to the mesosphere, Atmos. Chem. Phys., 6, 50675104, doi:10.5194/acp-6-5067-2006, 2006.

Jöckel, P., Kerkweg, A., Pozzer, A., Sander, R., Tost, H., Riede, H., Baumgaertner, A., Gromov, S., and Kern, B.: Development cycle 2 of the Modular Earth Submodel System (MESSy2), Geosci. Model Dev., 3, 717-752, doi:10.5194/gmd-3-717-2010, 2010.

Jöckel, P., Tost, H., Pozzer, A., Kunze, M., Kirner, O., Brenninkmeijer, C. A. M., Brinkop, S., Cai, D. S., Dyroff, C., Eckstein, J., Frank, F., Garny, H., Gottschaldt, K.-D., Graf, P., Grewe, V., Kerkweg, A., Kern, B., Matthes, S., Mertens, M., Meul, S., Neumaier, M., Nützel, M., Oberländer-Hayn, S., Ruhnke, R., Runde, T., Sander, R., Scharffe, D., and Zahn, A.: Earth System Chemistry integrated Modelling (ESCiMo) with the Modular Earth Submodel System (MESSy) version 2.51, Geosci. Model Dev., 9, 1153-1200, doi:10.5194/gmd-9-1153-2016, 2016.

Jurkat, T., Voigt, C., Kaufmann, S., Zahn, A., Sprenger, M., Hoor, P., Bozem, H., Müller, S., Dörnbrack, A., Schlager, H., Bönisch, $\mathrm{H}$., and Engel, A.: A quantitative analysis of stratospheric $\mathrm{HCl}$, $\mathrm{HNO}_{3}$, and $\mathrm{O}_{3}$ in the tropopause region near the subtropical jet, Geophys. Res. Lett., 41, 3315-3321, doi:10.1002/2013g1059159, 2014.

Jurkat, T., Kaufmann, S., Voigt, C., Schäuble, D., Jeßberger, P., and Ziereis, H.: The airborne mass spectrometer AIMS - Part 2: Measurements of trace gases with stratospheric or tropospheric origin in the UTLS, Atmos. Meas. Tech., 9, 1907-1923, doi:10.5194/amt-9-1907-2016, 2016.

Konopka, P., Grooß, J.-U., Günther, G., Ploeger, F., Pommrich, R., Müller, R., and Livesey, N.: Annual cycle of ozone at and above the tropical tropopause: observations versus simulations with the Chemical Lagrangian Model of the Stratosphere (CLaMS), Atmos. Chem. Phys., 10, 121-132, doi:10.5194/acp-10-121-2010, 2010 .
Kunze, M., Braesicke, P., Langematz, U., Stiller, G., Bekki, S., Brühl, C., Chipperfield, M., Dameris, M., Garcia, R., and Giorgetta, M.: Influences of the Indian Summer Monsoon on Water Vapor and Ozone Concentrations in the UTLS as Simulated by Chemistry-Climate Models, J. Climate, 23, 3525-3544, 10.1175/2010jcli3280.1, 2010.

Kunze, M., Braesicke, P., Langematz, U., and Stiller, G.: Interannual variability of the boreal summer tropical UTLS in observations and CCMVal-2 simulations, Atmos. Chem. Phys., 16, 8695-8714, doi:10.5194/acp-16-8695-2016, 2016.

Lawrence, M. G. and Lelieveld, J.: Atmospheric pollutant outflow from southern Asia: a review, Atmos. Chem. Phys., 10, 1101711096, doi:10.5194/acp-10-11017-2010, 2010.

Lelieveld, J., Crutzen, P. J., Ramanathan, V., Andreae, M. O., Brenninkmeijer, C. A. M., Campos, T., Cass, G. R., Dickerson, R. R., Fischer, H., de Gouw, J. A., Hansel, A., Jefferson, A., Kley, D., de Laat, A. T. J., Lal, S., Lawrence, M. G., Lobert, J. M., Mayol-Bracero, O. L., Mitra, A. P., Novakov, T., Oltmans, S. J., Prather, K. A., Reiner, T., Rodhe, H., Scheeren, H. A., Sikka, D., and Williams, J.: The Indian Ocean Experiment: Widespread Air Pollution from South and Southeast Asia, Science, 291, 10311036, doi:10.1126/science.1057103, 2001.

Li, Q., Jiang, J. H., Wu, D. L., Read, W. G., Livesey, N. J., Waters, J. W., Zhang, Y., Wang, B., Filipiak, M. J., Davis, C. P., Turquety, S., Wu, S., Park, R. J., Yantosca, R. M., and Jacob, D. J.: Convective outflow of South Asian pollution: A global CTM simulation compared with EOS MLS observations, Geophys. Res. Lett., 32, L14826, doi:10.1029/2005g1022762, 2005.

Livesey, N. J., Logan, J. A., Santee, M. L., Waters, J. W., Doherty, R. M., Read, W. G., Froidevaux, L., and Jiang, J. H.: Interrelated variations of $\mathrm{O}_{3}, \mathrm{CO}$ and deep convection in the tropical/subtropical upper troposphere observed by the Aura Microwave Limb Sounder (MLS) during 2004-2011, Atmos. Chem. Phys., 13, 579-598, doi:10.5194/acp-13-579-2013, 2013.

Marcy, T. P., Fahey, D. W., Gao, R. S., Popp, P. J., Richard, E. C., Thompson, T. L., Rosenlof, K. H., Ray, E. A., Salawitch, R. J., Atherton, C. S., Bergmann, D. J., Ridley, B. A., Weinheimer, A. J., Loewenstein, M., Weinstock, E. M., and Mahoney, M. J.: Quantifying Stratospheric Ozone in the Upper Troposphere with in Situ Measurements of $\mathrm{HCl}$, Science, 304, 261265, doi:10.1126/science.1093418, 2004.

Müller, S., Hoor, P., Bozem, H., Gute, E., Vogel, B., Zahn, A., Bönisch, H., Keber, T., Krämer, M., Rolf, C., Riese, M., Schlager, H., and Engel, A.: Impact of the Asian monsoon on the extratropical lower stratosphere: trace gas observations during TACTS over Europe 2012, Atmos. Chem. Phys., 16, 10573-10589, doi:10.5194/acp-16-10573-2016, 2016.

Nützel, M., Dameris, M., and Garny, H.: Movement, drivers and bimodality of the South Asian High, Atmos. Chem. Phys., 16, 14755-14774, doi:10.5194/acp-16-14755-2016, 2016.

Pan, L. L., Honomichl, S. B., Kinnison, D., Abalos, M., Randel, W. J., Bergman, J. W., and Bian, J.: Transport of chemical tracers from the boundary layer to stratosphere associated with the dynamics of the Asian summer monsoon, J. Geophys. Res.-Atmos., 121, 1-16, doi:10.1002/2016JD025616, 2016.

Park, M., Randel, W. J., Gettelman, A., Massie, S. T., and Jiang, J. H.: Transport above the Asian summer monsoon anticyclone inferred from Aura Microwave Limb Sounder tracers, J. Geophys. Res., 112, D16309, doi:10.1029/2006jd008294, 2007. 
Park, M., Randel, W. J., Emmons, L. K., Bernath, P. F., Walker, K. A., and Boone, C. D.: Chemical isolation in the Asian monsoon anticyclone observed in Atmospheric Chemistry Experiment (ACE-FTS) data, Atmos. Chem. Phys., 8, 757-764, doi:10.5194/acp-8-757-2008, 2008.

Park, M., Randel, W. J., Emmons, L. K., and Livesey, N. J.: Transport pathways of carbon monoxide in the Asian summer monsoon diagnosed from Model of Ozone and Related Tracers (MOZART), J. Geophys. Res., 114, D08303, doi:10.1029/2008jd010621, 2009.

Ploeger, F., Gottschling, C., Griessbach, S., Grooß, J.-U., Guenther, G., Konopka, P., Müller, R., Riese, M., Stroh, F., Tao, M., Ungermann, J., Vogel, B., and von Hobe, M.: A potential vorticitybased determination of the transport barrier in the Asian summer monsoon anticyclone, Atmos. Chem. Phys., 15, 13145-13159, doi:10.5194/acp-15-13145-2015, 2015.

Plumb, R. A.: Dynamical constraints on monsoon circulations, in: The Global Circulation of the Atmosphere, Princeton Univ. Press, Princeton, 252-266, 2005.

Randel, W. J. and Park, M.: Deep convective influence on the Asian summer monsoon anticyclone and associated tracer variability observed with Atmospheric Infrared Sounder (AIRS), J. Geophys. Res., 111, D12314, doi:10.1029/2005jd006490, 2006.

Randel, W. J., Pan, L. L., and Bian, J.: Workshop on dynamics, transport and chemistry of the UTLS Asian Monsoon, Adv. Atmos. Sci., 33, 1096-1098, doi:10.1007/s00376-016-6169-9, 2016.

Rauthe-Schöch, A., Baker, A. K., Schuck, T. J., Brenninkmeijer, C. A. M., Zahn, A., Hermann, M., Stratmann, G., Ziereis, H., van Velthoven, P. F. J., and Lelieveld, J.: Trapping, chemistry, and export of trace gases in the South Asian summer monsoon observed during CARIBIC flights in 2008, Atmos. Chem. Phys., 16, 3609-3629, doi:10.5194/acp-16-3609-2016, 2016.

Ren, R., Wu, G., Cai, M., Sun, S., Liu, X., and Li, W.: Progress in Research of Stratosphere-Troposphere Interactions: Application of Isentropic Potential Vorticity Dynamics and the Effects of the Tibetan Plateau, J. Meteor. Res., 28, 714-731, doi:10.1007/s13351-014-4026-2, 2014.

Righi, M., Eyring, V., Gottschaldt, K.-D., Klinger, C., Frank, F., Jöckel, P., and Cionni, I.: Quantitative evaluation of ozone and selected climate parameters in a set of EMAC simulations, Geosci. Model Dev., 8, 733-768, doi:10.5194/gmd-8-733-2015, 2015.

Roeckner, E., Brokopf, R., Esch, M., Giorgetta, M. A., Hagemann, S., Kornblueh, L., Manzini, E., Schlese, U., and Schulzweida, U.: Sensitivity of simulated climate to horizontal and vertical resolution in the ECHAM5 atmosphere model, J. Climate, 19, 37713791, 2006.

Schiller, C. L., Bozem, H., Gurk, C., Parchatka, U., Königstedt, R., Harris, G. W., Lelieveld, J., and Fischer, H.: Applications of quantum cascade lasers for sensitive trace gas measurements of $\mathrm{CO}, \mathrm{CH}_{4}, \mathrm{~N}_{2} \mathrm{O}$ and $\mathrm{HCHO}$, Appl. Phys. B, 92, 419-430, doi:10.1007/s00340-008-3125-0, 2008.
Schumann, U. and Huntrieser, H.: The global lightning-induced nitrogen oxides source, Atmos. Chem. Phys., 7, 3823-3907, doi:10.5194/acp-7-3823-2007, 2007.

Schumann, U., Konopka, P., Baumann, R., Busen, R., Gerz, T., Schlager, H., Schulte, P., and Volkert, H.: Estimate of diffusion parameters of aircraft exhaust plumes near the tropopause from nitric oxide and turbulence measurements, J. Geophys. Res., 100, 14147-14162, 1995.

Tost, H., Lawrence, M. G., Brühl, C., Jöckel, P., The GABRIEL Team, and The SCOUT-O3-DARWIN/ACTIVE Team: Uncertainties in atmospheric chemistry modelling due to convection parameterisations and subsequent scavenging, Atmos. Chem. Phys., 10, 1931-1951, doi:10.5194/acp-10-1931-2010, 2010.

Ungermann, J., Blank, J., Dick, M., Ebersoldt, A., Friedl-Vallon, F., Giez, A., Guggenmoser, T., Höpfner, M., Jurkat, T., Kaufmann, M., Kaufmann, S., Kleinert, A., Krämer, M., Latzko, T., Oelhaf, H., Olchewski, F., Preusse, P., Rolf, C., Schillings, J., Suminska-Ebersoldt, O., Tan, V., Thomas, N., Voigt, C., Zahn, A., Zöger, M., and Riese, M.: Level 2 processing for the imaging Fourier transform spectrometer GLORIA: derivation and validation of temperature and trace gas volume mixing ratios from calibrated dynamics mode spectra, Atmos. Meas. Tech., 8, 2473 2489, doi:10.5194/amt-8-2473-2015, 2015.

Vogel, B., Günther, G., Müller, R., Grooß, J.-U., and Riese, M.: Impact of different Asian source regions on the composition of the Asian monsoon anticyclone and of the extratropical lowermost stratosphere, Atmos. Chem. Phys., 15, 13699-13716, doi:10.5194/acp-15-13699-2015, 2015.

Voigt, C., Jessberger, P., Jurkat, T., Kaufmann, S., Baumann, R., Schlager, H., Bobrowski, N., Giuffrida, G., and Salerno, G.: Evolution of $\mathrm{CO}_{2}, \mathrm{SO}_{2}, \mathrm{HCl}$, and $\mathrm{HNO}_{3}$ in the volcanic plumes from Etna, Geophys. Res. Lett., 41, 2196-2203, doi:10.1002/2013GL058974, 2014.

Yan, X., Wright, J. S., Zheng, X., Livesey, N. J., Vömel, H., and Zhou, X.: Validation of Aura MLS retrievals of temperature, water vapour and ozone in the upper troposphere and lower-middle stratosphere over the Tibetan Plateau during boreal summer, Atmos. Meas. Tech., 9, 3547-3566, doi:10.5194/amt-9-3547-2016, 2016.

Zahn, A., Weppner, J., Widmann, H., Schlote-Holubek, K., Burger, B., Kühner, T., and Franke, H.: A fast and precise chemiluminescence ozone detector for eddy flux and airborne application, Atmos. Meas. Tech., 5, 363-375, doi:10.5194/amt-5-363-2012, 2012.

Ziereis, H., Schlager, H., and Schulte, P.: Distributions of NO, $\mathrm{NO}_{x}$, and $\mathrm{NO}_{y}$ in the upper troposphere and lower stratosphere between $28^{\circ}$ and $61^{\circ} \mathrm{N}$ during POLINAT 2, J. Geophys. Res., 105, 3653-3664, doi:10.1029/1999JD900870, 2000. 